
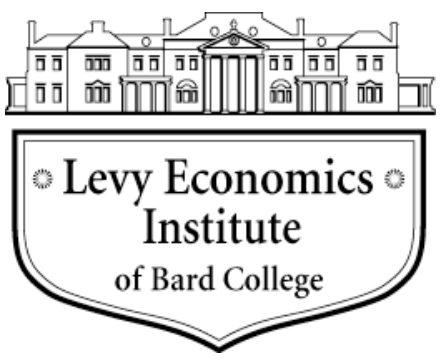

Working Paper No. 783

\title{
Options for China in a Dollar Standard World: A Sovereign Currency Approach*
}

by

\author{
L. Randall Wray \\ Levy Economics Institute of Bard College \\ Xinhua Liu \\ Shaanxi Normal University, China
}

January 2014

\begin{abstract}
* This paper is written under contract No. 104770-A77922, SC101253, PRC: MMT for PRC, Asian Development Bank. The authors thank the ADB for funding, and especially thank Jesus Felipe and Yolanda Fernandez Lommen for their support and comments. The views expressed in this paper are those of the authors and do not necessarily reflect the views and policies of the ADB or its Board of Governors or the governments they represent. The ADB does not guarantee the accuracy of the data included in this publication and accepts no responsibility for any consequence of its use.
\end{abstract}

The Levy Economics Institute Working Paper Collection presents research in progress by Levy Institute scholars and conference participants. The purpose of the series is to disseminate ideas to and elicit comments from academics and professionals.

Levy Economics Institute of Bard College, founded in 1986, is a nonprofit, nonpartisan, independently funded research organization devoted to public service. Through scholarship and economic research it generates viable, effective public policy responses to important economic problems that profoundly affect the quality of life in the United States and abroad.

\author{
Levy Economics Institute \\ P.O. Box 5000 \\ Annandale-on-Hudson, NY 12504-5000 \\ http://www.levyinstitute.org
}

Copyright (C) Levy Economics Institute 2014 All rights reserved

ISSN 1547-366X 


\begin{abstract}
This paper examines the fiscal and monetary policy options available to China as a sovereign currency-issuing nation operating in a dollar standard world. We first summarize a number of issues facing China, including the possibility of slower growth, global imbalances, and a number of domestic imbalances. We then analyze current monetary and fiscal policy formation and examine some policy recommendations that have been advanced to deal with current areas of concern. We next outline the sovereign currency approach and use it to analyze those concerns. We conclude with policy recommendations consistent with the policy space open to China.
\end{abstract}

Keywords: China; Policy Space; Fiscal and Monetary Policy; Sectoral Balances Approach; Minsky; Sovereign Currency; Modern Money Theory; Middle-Income Trap; Financial Instability

JEL Classifications: E2, E5, E6, F4, G2, G3, H5, H6, H7, H63, H72 


\section{SUMMARY}

Our main conclusions are these: (1) China's fiscal and monetary policy space is similar to that of other monetarily sovereign nations such as the United States, the UK, and Japan. Therefore, (2) "affordability" is not an issue: China's central government can always make all budgeted payments as they come due; and (3) the overnight interest rate is a policy variable, determined by China. Further, (4) these results do not depend on internationalization of the sovereign currency; (5) nor do they require that China "liberalize" capital flows. China's main imbalance is domestic and consists of local government budgets that are too loose, while the central government's budget is too tight. While local governments do face a solvency constraint, the central government - as a currency issuer-does not.

Following from these conclusions, we recommend that the central government's fiscal stance should be gradually relaxed so that local government and corporate budgets can be tightened. By loosening the central government's budget but tightening local government and corporate budgets at a measured pace, China can avoid depressing growth or sparking excessive inflation. 


\section{TABLE OF CONTENTS}

I. Background and Context for the Analysis

II. A Quick Review of the Relevant Economic Situation of China

III. Quick Overview of Current Policy Making in China

1. Monetary Policy

2. Fiscal Policy

IV. Implications of Fixed Exchange Rate Systems

V. An Alternative Approach: Sovereign Currencies

VI. Implications for China

1. Sectoral Balances and Government Budgets

2. Policy Options

VII. Lessons from the GFC

VIII. Conclusions 
This paper addresses the fiscal and monetary policy options that are open to China as a sovereign currency-issuing nation. Today China operates with what many call a "fiat" currency, but in what could be called a "dollar standard" world in the sense that the vast majority of international transactions are denominated (and, often, cleared) in dollars. ${ }^{1}$ Further, China chooses to closely manage its exchange rate. Some have encouraged China to not only move toward greater flexibility of exchange rates, and toward freer capital markets, but also toward internationalization of the renminbi (RMB). While we believe that the RMB will be increasingly used to denominate international transactions and that it could eventually replace the dollar as the most important global currency, this paper explores the policy space already available to China. In our view, as a sovereign currency-issuer, China already has the fiscal capacity to continue to pursue economic growth at a pace consistent with its development objectives.

The potential obstacle facing China is that it might not take advantage of the policy space it already has. Indeed, in recent weeks there has been talk of reigning in the central government's budget, apparently on the belief that fiscal deficits are dangerous. This is somewhat surprising as the West has simultaneously discovered that fiscal policy is too tight, and that the "growth through austerity" experiment adopted in the US, the UK, and much of Europe is failing. It would be a mistake, in our view, for China to now pursue this discredited policy. It is also necessary to understand why a country that issues its own currency has much more policy space than one that adopts or pegs to a foreign currency (or a precious commodity like gold). It really is necessary for a country on a gold standard or a currency board to be careful about running budget deficits. There is also a growing recognition that the countries that joined the European Monetary Union (EMU) effectively gave up currency sovereignty, so their policy options are severely constrained. But countries like the US, the UK, and China are monetarily sovereign and that makes a big difference. Just how different they are is only gradually becoming recognized, however, by policymakers and economists.

There is an alternative tradition in economics that has long appreciated the advantages offered by sovereign currencies. This paper will apply that approach to the case of China. It will be argued that with its own "fiat" currency, China's central government can "afford" to spend enough to keep the nation on its desired development path - even if that means that the budget

\footnotetext{
${ }^{1}$ See, for example, "The Unloved Dollar Standard: From Bretton Woods to the Rise of China", draft paper by Ronald McKinnon (October 9, 2012). 
continues to show a deficit. To be sure, too much government spending can be bad-it can cause inflation and can possibly exert pressure on the exchange rate. Hence, the budgeting process needs to be on guard against excessive spending that would lead to inflation, but there is no a priori reason to eschew budget deficits because the issue of "too much spending" is not "affordability" but rather "inflation".

To be sure, inflation is a concern and even possibly a danger. However, it is important not to confuse these too issues. Excessive government spending does raise the prospect of fueling inflation. As such, it is not the purpose of this paper to necessarily argue for greater government spending. Rather, this paper will make the argument that, holding total spending across all sectors constant, for reasons to be explained it is desirable to shift spending between sectors - from sectors that have limited fiscal capacity to the sovereign central government that has more fiscal policy space.

The paper will demonstrate that:

1. China's fiscal and monetary policy space is similar to the cases of other monetarily sovereign nations such as the US, the UK, and Japan²;

Therefore,

2. "affordability" is not an issue: China's central government can always make all budgeted payments as they come due; and

3. the overnight interest rate is a policy variable, determined by the People's Bank of China (PBC).

Further,

4. these results do not depend on internationalization of the sovereign currency;

5. nor do they require that China "liberalize" capital flows.

\footnotetext{
${ }^{2}$ For a detailed examination of the policy space available to sovereign currency issuing governments, see L. Randall Wray, Modern Money Theory: A Primer on Macroeconomics for Sovereign Monetary Systems ", PalgraveMacmillan, New York, 2012. For applications of this approach to China: "Excessive Liquidity and Bank Lending in China: A Modern Money Perspective", Xinhua Liu and L. Randall Wray), International Journal of Political Economy, Volume 39, Number 3, Fall 2010, pp. 45 - 63; "Lessons for China from the Crisis in Euroland" (Xinhua Liu and L. Randall Wray), The Chinese Economy, Vol. 1 Issue 2012; and "The Nature of Money: From the View of Post-Keynesian Economics" (L. Randall Wray and Jinxing Guo); China Review Of Political Economy, No.1, 2012.
} 
In other words, China already has the domestic policy space the nation needs to pursue its domestic policy agenda.

Finally, the paper will identify some problem areas that should be addressed. Importantly, we address potential problems in China's macroeconomic sectoral balances. The corporate sector and the local government sector are probably issuing too much debt relative to their income flows, while the central government is issuing too little. That might seem like a surprising conclusion but it follows from the understanding of the relations between the sovereign currency issuer and the users of that currency. Corporations, households, and local governments are users of the RMB and if central government policy is too tight, economic growth requires that the balance sheets of the currency users become more precarious. This tendency will be compounded if China's current account surplus is reduced or if the central government tries to move toward a balanced budget. There is growing recognition that financial fragility exists across some sectors of the Chinese economy but the relationship to central government finances has not been understood. For that reason, our main policy recommendation will be:

6. The central government's fiscal stance should be gradually relaxed so that local government and corporate budgets can be tightened. By loosening the central government's budget, but tightening local government and corporate budgets at a measured pace, China can avoid depressing growth or sparking excessive inflation.

These six points will be the main contributions made by this paper.

We next provide a brief overview of the background for this research, quickly summarizing the most important economic issues facing China today. We put that in the context of a growing consensus that economists and policymakers have overestimated the importance of monetary policy and underestimated the usefulness of fiscal policy. At the same time, they are recognizing that the excessive fear of budget deficits that generated support for "growth through austerity" experiments were a mistake. We argue that if economists and policymakers had recognized that sovereign currency regimes really are different, a lot of suffering could have been avoided. It is in this context that we turn to an analysis of China's situation. 


\section{BACKGROUND AND CONTEXT FOR THE ANALYSIS}

Since adopting a policy of gradually opening its economy, China has enjoyed rapid economic growth and rising living standards for much of its population. Some prominent commentators have, rightly in our view, attributed China's success in part due to its approach to exchange rate stabilization policy in the context of a "dollar standard" world. Given the willingness of the US to supply the international reserve currency, countries like China have been able to find external markets for output while accumulating very large international reserves to cushion unexpected shocks. Even with the greatest international financial crisis since the Great Depression, China managed to weather the disruption with relative ease.

We agree with the argument made by some that China is not now in a position to fully liberalize its capital markets nor to float its currency. Given its large dollar reserves, China will be able to successfully manage its exchange rate for domestic policy purposes. But opening capital markets excessively could possibly subject China's financial markets to the same sorts of abuses that created crises in most of the Western world after 2008. Continued capital controls help to insulate China from what are almost certain to be trying times to come. We cannot rule out another financial crisis will hit the global economy within the next few years. Some parts of the global economy have not recovered from the last crisis, and others are actually slipping back into recession. ${ }^{3}$ Further, the managed exchange rate regime in the current environment helps to reduce uncertainty.

China, too, has slowed and some commentators think China's growth will not return to its previously high rates. Even if it does manage to resume high growth rates in the near-tomedium term, some argue that China might not avoid the "middle income trap" as its GDP per capita reaches $\$ 18,000$ (current dollars) by the 2020s. It is possible, however, that commentators might be underestimating China's ability to continue to grow at a rapid pace. ${ }^{4}$

\footnotetext{
${ }^{3}$ See, for example, “2013 Macroeconomic Outlook and Monetary Policy View: No Exit from the Wasteland?", by Tanweer Akram, ING Global Macro View from Atlanta, GA, ING Investment Management report, Nov 12, 2012.

${ }^{4}$ See George Magnus "China and the End of Extrapolation", Wednesday, May 01, 2013; "Is Asia's Miracle Over?" Thursday, May 02, 2013; "Hitting a BRIC Wall", May 3, 2013; all available at http://www.theglobalist.com/storyid.aspx?storyid=9981 and at http://georgemagnus.com/articles_and_interviews/china-and-the-end-of-extrapolation.
} 
Other commentators worry about "global imbalances"-current account deficits in some countries and surpluses in others. In the view of many, China's high growth rate depends on continued "undersaving" by US consumers and "oversaving” by Chinese (and other Asian) households. ${ }^{5}$ Indeed, many attribute the global financial crisis to a huge flow of "liquidity" from the developing world to finance excessive US consumption fueled by low interest rates in the West due to all that saving in the East. Further, some argue that current extremely low interest rates in the West are fueling the "carry trade"-borrowing cheaply in the US to lend in the BRICs and elsewhere. Thus, we have another "global imbalance" that will not be sustained, according to such thinking. If that is correct, then China's high growth could be threatened.

Some have pushed for creation of a new international currency regime, perhaps a new Bretton Woods system, or perhaps one formulated along the lines of the Bancor plan advanced by John Maynard Keynes in the 1940s. The Keynes plan would be a system of fixed exchange rates with an automatic adjustment mechanism. This could resolve both the exchange rate issues as well as the global imbalance issues previously mentioned. However, if the reform really did follow the Keynes plan, it is probable that the adjustment mechanism would reduce China's trade surplus. For that reason, it is possible that such a regime would lead to slower growth in China. At the very least, it would indicate that China should focus more of its efforts to domestic demand rather than to relying on external demand.

Some have argued that China should itself pursue a goal of establishing the renminbi as an international reserve currency. This might require that China a) open capital markets substantially, b) become a supplier of RMB for global trade (either through current account deficits or through international lending), and c) assume some responsibility for external financial institutions. For example, when the global financial crisis hit, the US Fed had to lend literally trillions of dollars internationally to quell the liquidity crisis. Such issues need to be carefully considered before moving in this direction.

Further some have warned that China's reliance on a huge supply of labor coming from the agricultural sector will soon come to an end as most of the excess has already been absorbed by industry (again, see Magnus, cited in note 4.). If that is true, then growth attributed to raising

\footnotetext{
${ }^{5}$ For a detailed analysis, see "The People's Republic of China and Global Imbalances from a View of Sectorial Reforms”, by Hiro Ito and Ulrich Volz, ADBI Working Paper Series No. 393, November 2012, Asian Development Bank Institute.
} 
labor productivity by shifting from agriculture to manufacturing will slow as these gains are exhausted.

While China's growth so far can be attributed to gradual market reform with substantial state guidance, some argue that maintaining robust growth will require greater openness and continued market reform. In particular, it is argued that subjecting the financial sector to market forces while reducing financial repression (low interest rate policy) and reduced government support for state owned enterprises (SOEs) as well as state banks would improve the allocation of financial resources. Greater use of a market approach to monetary policy (rather than nonmarket approaches including credit constraints) while focusing policy on inflation targets would be consistent with such reform.

Finally, some commentators have recently raised the issue of fragile finances within China. Growth of the shadow banking system as well as relatively rapid growth of indebtedness in some sectors might indicate that instability could come from the domestic economy rather than from abroad. Some worry about the finances of local governments. Although the national government's budget balances are strong, local governments have incurred very large debts so they might have to reduce spending. Again, all of this might mean that the high growth rates of the past — if they relied excessively on too much debt creation — would not be sustainable for the future. The residential real estate sector as well as commercial real estate could be in trouble, and at least some local governments might face default. Furthermore, even though national government deficits and debts are quite small, off-balance-sheet commitments are large. Thus, it is argued, fiscal space is actually much smaller than it appears and might not be sufficient to deal with a serious financial crisis and economic downturn.

Our project examines many of these issues with a view to providing policy recommendations that would allow China to maintain robust growth in a sustainable manner. We will not, however, examine every issue in detail. Rather what we want to do is to provide a new framework for analyzing these issues. We will use a relatively new approach to economics - and especially to monetary and fiscal policy - that is based on the recognition that policy options open to a nation that issues its own "fiat" or "sovereign" currency are much greater than the narrow policy space available to nations that do not. While it is relatively new, the components of the theory are actually based on well-established macroeconomic theories that date back a century or more. Many commentators do not recognize the difference between a 
sovereign currency-issuing government and a government that does not issue its own currency. However, this difference is fundamental and leads to a much more open menu of policy options than is usually thought to be the case. ${ }^{6}$

The global financial crisis and severe economic downturn in the West have initiated rethinking on these matters. Before the crisis, there was a widespread belief that monetary policy is the most important tool for economic stabilization. The importance of fiscal policy was downplayed. Nowhere was this more obvious than in the set-up of the European Monetary Union where monetary policy power was consolidated in the European Central Bank (ECB), which was given nearly complete independence from the highly decentralized and relatively weak fiscal policy of the nation states. When the global financial crisis (GFC) hit, some countries (notably, the US, the UK, and China) turned to fiscal policy stimulus, but the EMU had no centralized fiscal authority to ramp-up spending. Two years into the crisis, the US and UK began recoveries, but the EMU crisis actually began to deepen in 2010. Even today, many EMU members remain mired in very deep recession.

Led by mainstream economic theory, policymakers in the West began to adopt a new approach sometimes referred to as "fiscal consolidation" or "growth through austerity". This approach was applied most forcefully on the periphery of the EMU, but also to a lesser extent in the UK and the US (after recovery began). The basic argument was that reducing budget deficits would allow the private sector to grow more robustly and thereby lift economic growth. Two important empirical research programs provided apparently rigorous justification for this approach - the first purported to show that high government debt-to-GDP ratios generate financial crises, while the second purported to demonstrate that due to crowding out, the government spending "multiplier" is much smaller than conventionally supposed (and, indeed, could be negative). ${ }^{7}$ Over the course of the past several months, however, both of these claims

\footnotetext{
${ }^{6}$ Economists have long used the term "fiat currency" to mean a currency issued by a government that does not promise to convert it to precious metal or foreign exchange at a fixed exchange rate. We prefer to use the term "sovereign currency", emphasizing that this is a currency issued by sovereign government, denominated in the money of account chosen by the sovereign government, and accepted by that government in payments made to itself. The government also chooses an exchange rate regime, with a fixed exchange rate on one extreme, a free float on the other, and with a managed float in between the extremes. As we will discuss, the fixed exchange rate regime provides the least domestic policy space; managed and floating generally offer more. (See Wray 2012, Modern Money Theory cited above.)

${ }^{7}$ Reinhart and Rogoff and Alesina are the main proponents of each of these arguments. See Levy Economics Institute Working Paper No. 603, "Does Excessive Sovereign Debt Really Hurt Growth? A Critique of This Time Is Different, by Reinhart and Rogoff", by Yeva Nersisyan L. Randall Wray, June 2010 for an early critique; "Is the
} 
have been challenged. The finding that there is a debt ratio threshold (purported to be at 90\%) was shown to rely on flawed empirical work. And more recent estimates by International Monetary Fund (IMF) economists of the spending multiplier have shown that it is actually significant. In both cases, then, it appears that fiscal stimulus actually does work and that even fairly high government debt ratios do not generate substantially slower economic growth. A consensus is emerging that fiscal policy is important, after all, and that budget deficits don't necessarily burden an economy.

A recent empirical paper carefully investigates the claim that "big government", especially one that provides a generous social safety net, leads to poor economic performance due to inefficiencies. ${ }^{8}$ The authors note that most developed Western nations have cut social spending on the argument that government spending is less productive than private spending, and that taxes reduce spending in the more efficient private sector. Hence, downsizing government was supposed to increase efficiency and generate greater growth. The authors examine the cases of 15 European countries that followed this advice and find no evidence for the claim that reducing the size of government enhances economic performance.

These results are entirely in line with what the sovereign currency approach has been arguing. The error that has been made (especially in the empirical work that purported to show that higher debt ratios lead to slower growth) is the failure to recognize that the currency regime matters. A nation that adopts a gold standard or a foreign currency (as in a currency board arrangement), or that issues government debt denominated in a foreign currency, can quickly get into financial trouble if it runs sizable deficits. The situation is quite different for a nation that

U.S. on an Unsustainable Path? Lessons from the Past as Detailed by Reinhart and Rogoff', L. Randall Wray and Yeva Nersisyan, in Onaran, O., Torsten Niechoj, Engelbert Stockhammer, Achim Truger, and Till van Treeck (eds.) Stabilizing an Unequal Economy? Public Debt, Financial Regulation, and Income Distribution, Metropolis Marburg, October 2011 for an argument that the Rogoff-Reinhart results are not relevant to the US case; and "Does High Public Debt Consistently Stifle Economic Growth? A Critique of Reinhart and Rogoff", by Thomas Herndon, Michael Ash and Robert Pollin 4/15/2013 for evidence that the Reinhart and Rogoff results depended on mistakes made in data analysis. See IMF Working Paper "Growth Forecast Errors and Fiscal Multipliers" by Olivier Blanchard and Daniel Leigh, January 2013 http://www.imf.org/external/pubs/ft/wp/2013/wp1301.pdf for the argument that "fiscal consolidation" (tighter government budgets) have had larger than expected negative effectsindicating empirical evidence in support of a government spending multiplier.

8 "Does cutting back the public sector improve efficiency? Some evidence from 15 European countries"; Working Paper by Sabrina Auci (University of Palermo), Laura Castellucci (University of Rome "Tor Vergata"), and Manuela Coromaldi (University of Rome "Niccolò Cusano); 2013-04-30; URL: http://d.repec.org/n?u=RePEc:rtv:ceisrp:274\&r=his 
issues its own sovereign currency, and that restricts government debt issuance only to its own currency. This paper will explain why sovereign currency matters.

This issue is particularly important for China as the nation moves forward. In recent weeks, there has been a move in China to reign in central government deficits, and, as discussed above, there has for some time been support for the creation of a new international monetary system. It is somewhat surprising that China would now be worried about its very small central government deficits and debt—as these are denominated in China's own sovereign currencygiven the growing recognition that economists and policymakers in the West had been unnecessarily alarmist about much higher budget deficits and debt ratios in countries like the US, the UK, and Japan.

This paper will argue that a more prudent course for China would actually be to relax central government fiscal policy. Indeed, for reasons we will make clear, this is a necessary move in order to improve the finances of local governments as well as corporations. We do appreciate the concern with inflation. Our point, however, is that China's central government spending is very small in comparison with both developed and middle income developing nations. If there are indeed inflation pressures, they are not likely to be currently due to excessive central government spending. Rather, they could be fueled by a combination of speculation (real estate) and bottlenecks (skilled labor and certain commodities) and should be mitigated through directed policy action rather than by constraining central government spending. Indeed, if aggregate demand is currently at the correct level, then it is possible to relax central government budgets while at the same time tightening local government and corporate balances so as to hold total aggregate spending constant. This would enhance financial stability without giving up price stability. If desired, other measures can also be pursued - tighter monetary policy, direct credit controls, restrictions on speculation, and so on. The point is that shifting more fiscal responsibility to the central government does not eliminate the possibility of using other means to fight inflation.

And, finally, while we take no position on the internationalization of the RMB or on the reformation of the international monetary system, we do recommend that China preserve its domestic policy space by retaining its own sovereign currency.

We first quickly review the current situation in China. This will provide a starting point for our detailed analysis that adopts the sovereign currency approach to analysis. It is our view 
that this approach provides policy guidance that preserves and indeed expands policy space. By contrast, many of the recommendations that come from the conventional (and formerly dominant) perspective would actually narrow ability of government to promote development and growth and as well to respond to crises. It is our view that conventional wisdom is unnecessarily defeatist — we do not believe that there is an inevitable "middle income trap" that will cause China's growth to stall within a decade. However, if policy-makers were to follow the economic advice provided by conventional wisdom, growth would most likely suffer. In other words, by adopting policies such as balancing the central government's budget, the feared results might actually be induced. If, instead, policy makers understand how they can use monetary and fiscal policies, they will not only avoid the middle income trap, but they will promote continued growth and development after that threshold is passed within the next few years.

\section{A Quick Review of the Relevant Economic Situation of China}

\section{National Government Finances}

Below we will examine in detail China's central government debt and deficit ratios. While China's government debt ratio has grown in the most recent years (from below $20 \%$ of GDP to more than $33 \%$ in 2001, although it came down to $26 \%$ in 2012), it remains well below ratios that are common in the West. Further its budget deficits are small (typically between one and two percent of GDP); it is also interesting that if we exclude central government funding of local government spending (through transfers and tax rebates), the central government's budget surplus would be very large and growing. Together, all of this would seem to indicate substantial "policy space" for expansion of central government spending if necessary, even based on conventional criteria.

The central government has announced plans to increase spending. As reported:

March 5 (Bloomberg) -- China plans to raise its budget deficit by 50 percent this year as the central government cuts taxes and boosts measures to support consumer demand in the world's second-biggest economy. The gap will widen to 1.2 trillion yuan $(\$ 193$ billion) in 2013 from 800 billion yuan last year, amounting to about 2 percent of gross domestic product, the Ministry of Finance said in its budget report to the National People's Congress in Beijing today. Local governments will run a combined deficit of 
350 billion yuan and the Ministry of Finance will issue bonds to cover their shortfall, according to the report.

This is an interesting, and in our view beneficial, move. Relieving local government budgets through Ministry of Finance bond issues should improve local budgets. All of this seems to indicate that the central government recognized it has the fiscal policy space to expand spending in order to keep the economy growing - at a targeted robust $7.5 \%$ annual rate.

Still, this newer announcement must be interpreted in the context of the earlier report that China's leadership would be emphasizing "quality" over "quantity" in its growth. As reported:

Feb. 28 (Bloomberg) -- Almost half of China's provinces are setting their growth sights lower in the wake of the central government's emphasis on the quality of expansion over speed, a sign of an increased focus on tackling rising debt. Fourteen provinces have set lower targets for gross domestic product expansion this year than in 2012 and the other 17 left their goals unchanged, according to Nomura Holdings Inc. The weighted average target has dropped to 9.9 percent from 10.3 percent, Citigroup Inc. calculates.

We will say a bit more about local government finances in a section below. Obviously there needs to be consistency between local government growth targets and central government targets. Trying to grow faster at the local level could mean running up debt at a faster pace than average (spending multipliers could cause income to leak out of a fast-growing region - this is a sort of "Thirlwall's Law" applied to regions within a country, in which by definition exchange rates are pegged since all use the RMB).

Further, a new report by the Citi AP Economics Research group believes that the 2013 budget contains less stimulus than estimated by the central government:

Proper accounting reveals less expansionary fiscal policy in 2013 - The proposed 2013 budget envisages a fiscal deficit of Rmb1.2tn, or about $2 \%$ of GDP, seemingly more expansionary than the 2012 budget and fiscal outcome (deficit of Rmb800bn, or $1.5 \%$ of GDP). However, the official fiscal accounting methodology is outdated and cannot accurately reflect the macro impact of the fiscal policy, in our view. Our calculation based on widely accepted fiscal accounting rules indicates the budget deficit for 2012 was $2.4 \%$ of GDP and the actual deficit was $2.0 \%$ of GDP. Considering that the actual deficit tends to undershoot the budgeted level, we take the view that fiscal policy in 2013 would be less expansionary relative to 2012 . 
The group projects a growth rate of $7.8 \%$ for this year. While there is some recent evidence showing that economic growth is moderating, we take no position on Citi's estimates relative to the central government's projections and in any case budgetary outcomes are to some extent nondiscretionary (slower growth can cause tax revenues to come in lower than expected, so that deficits can be larger than projected). The fact that the government announced a willingness to increase deficits seems to indicate that it believes there is plenty of policy space to stimulate the economy as necessary.

This view is not universally shared. For example, Goodfriend and Prasad ${ }^{9}$ argued that government's large contingent liabilities provide less room to maneuver than is commonly supposed. While the paper is a bit dated, most of their objections would still hold. Among other commitments the authors include potential liabilities due to "unviable" state owned enterprises and thus nonperforming loans on state bank balance sheets. For this reason, they argue that China will need to rely more heavily on monetary policy than fiscal policy. But that, in turn, suggests to them that the current exchange rate regime is inappropriate because it reduces monetary policy independence (desired interest rate targets could conflict with the desired exchange rate).

Finally, in recent weeks there have been growing calls for moving to a tighter central government fiscal stance. ${ }^{10}$ There has been growing support for moving toward a balanced budget. While such a move would make sense if inflation were rising at an out-of-control pace, that does not appear to be the case. Indeed, with the global economy cooling, it looks like the inflation in China is not due to a general excess of aggregate demand fueled by budget deficits

\footnotetext{
9 "Monetary policy implementation in China", by Marvin Goodfriend and Eswar Prasad, 2006, paper presented at HKIMR-BIS conference on "Monetary policy approaches and implementation in Asia". This paper draws extensively upon the authors' IMF Working Paper WP/06/111 “A Framework for Independent Monetary Policy in China", available on the web at www.imf.org.

${ }^{10}$ Here are three recent examples reflecting concern for the balance between government spending and revenues: a. Li Xudong, the director of Guangdong provincial government finance warned that national government revenue growth rate has been lower over the past four months, as income increased by just $6.7 \%$, while spending increased by $13.6 \%$. Further, he said that the Treasury's deposit in banks had fallen almost to zero by the end of March, 2013, so the Chinese government budget could incur an even greater deficit. He warned that it will be hard to achieve $8 \%$ growth of government income by the end of this year especially as it is central government revenue that is experiencing the biggest fall in growth rate. b. Chinese Ministry of Finance Research Institute Director Jia Kang said that it is hard to achieve the government's goal for revenue growth rate by the end of year 2013 and he felt very pessimistic about government revenue prospects. c. Chinese Counselor of the State Xiabing said that in future years, the Chinese treasury will encounter significant problems because its income growth will not keep pace with its spending, unless China tries to create tax systems to meet the gap. He believes this requires a long time for accomplishment. For more discussion along these lines, see http://economy.caijing.com.cn/2013-0515/112780267.html.
} 
that are too large. While there are significant bottlenecks, there are probably better ways of dealing with resulting inflation pressures than by tightening the fiscal stance. So it appears that the argument for reducing budget deficits does not rest on inflation but rather on the belief that deficits are bad for other reasons. In fact, it seems that the argument for less fiscal stimulus in China relies on the same views that drove the "growth through austerity" campaign in the West over the past few years.

The supposed reasons for running tight policy include, in addition to inflation, possible exchange rate effects (high growth can raise imports relative to exports), crowding out of investment (unlikely to be a problem in China today — as investment is extremely high), increased risk of sovereign insolvency (actually not possible for a sovereign currency-issuer as we'll explain below), or to preserve policy space for the future when it might really be needed ("keep the powder dry"). Indeed, after the GFC hit, many economists argued that a country like the US (which had a fairly small government debt ratio) was better situated than, say, a country like Italy (which already had a high debt ratio) to use fiscal stimulus. In our view, the "keep the powder dry" argument might apply to a country that does not issue a sovereign currency, but it cannot apply to a sovereign-issuer like the US or China.

As we will argue later in this paper, we believe China's fiscal policy space is adequate for now, and can be preserved by gradually relaxing control of the exchange rate. At the same time, we argue that it would be a mistake to shift the policy mix away from fiscal policy and toward a more market-based monetary policy. While we do recognize the substantial contingent liabilities of the national government, we believe that the best way to handle them is to make them more explicit.

In our view, China should move toward greater reliance on central government spending to keep growth on target. To be sure, on-budget fiscal stimulus is only a part of the impetus to growth. In addition, there is implicit "off-budget" stimulus in the form of state-encouraged lending and local government (deficit) spending. The corporate and household sectors also have provided stimulus through debt-financed spending. But these other forms of stimulus are potentially more troubling because they can enhance financial fragility, as we discuss in the following sections. Instead, China should increase on-budget spending, both direct spending as well as transfers to local government. Worries about current central government budget outcomes are misplaced. 
Understanding how much policy space is available to the sovereign currency-issuing central government will help to relieve any fears of fiscal deficits - a topic we turn to after finishing our discussion of current economic conditions in China. Once one understands the sovereign currency approach to fiscal policy, one realizes that policy space is indeed sufficient to "finance" stimulus to keep the economy near full employment. In that sense, it will be real resource availability — and thus the inflation barrier — that finally determines maximum growth potential.

\section{Corporate Debt}

While national government deficits and debt have been relatively small, figure 1 shows that China's corporate debt as a percent of GDP is high compared to that of some other Asian nations - and very much higher than the ratio in the US. (See the next chart.) However, it is no secret that China and some Asian nations have had very high investment ratios-which could be expected to lead to higher corporate debt ratios, all else equal.

Figure 1: Corporate Debt as a Percent of GDP, by Country

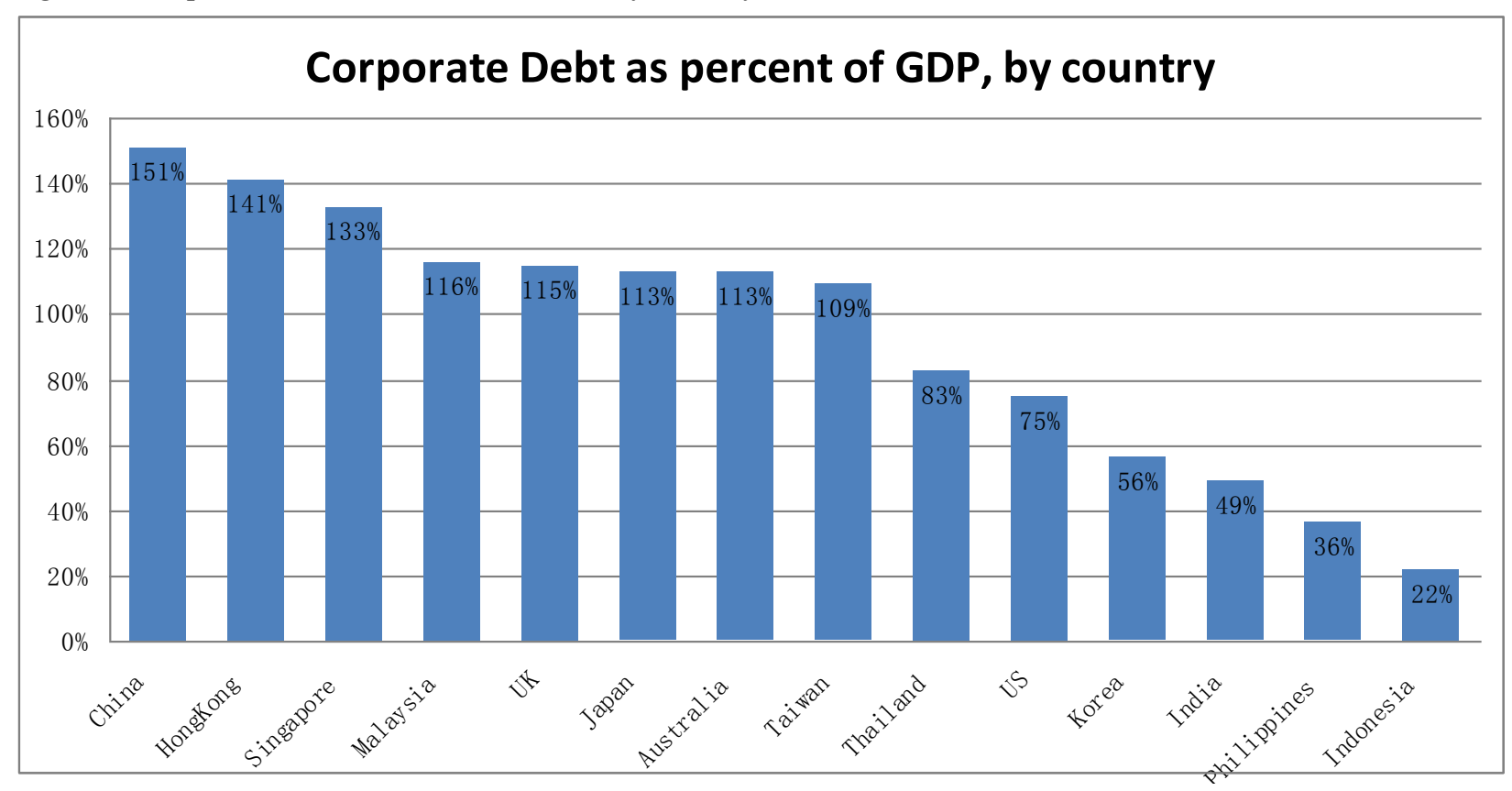

Source: Frank Veneroso (from data from Guo Hua Securities, Goldman Sachs, and Zero Hedge)

China's transformation over the past several decades could rightly be called unprecedented. While mainstream economics typically presumes diminishing returns, China is an example of an economy that achieved constant to increasing returns through massive public and private capital 
investment. In important respects, China followed development economist Paul RosensteinRodan's recommended path to development—which promoted rapid capital accumulation. China simultaneously built the entire complement of all industries as well as making social investments in infrastructure and education.

Rosenstein-Rodan had recognized that the "free" private market could not accomplish this, but China's planned economy was able to do it. China did not follow the narrower development path pursued by some Asian Tigers - which focused on particular sectors in which they would compete on a global scale. China built across the range of industries, and built on a big scale. Starting with relatively small domestic demand for some of these outputs, China needed to rely on exports in some areas - but again this was not strictly speaking the Tiger model of export-led growth. As the following table shows, China's growth rate has generally been higher than growth rates of the developing world in recent years ${ }^{11}$ :

Table 1: Growth Rate Comparison

\begin{tabular}{|c|c|c|c|}
\hline & NIEs (\%) & $\begin{array}{l}\text { China, People's } \\
\text { Republic of (\%) }\end{array}$ & Others (\%) \\
\hline \multicolumn{4}{|l|}{ 1992-1997 } \\
\hline Growth in output & 6.99 & 9.79 & 5.64 \\
\hline \multicolumn{4}{|l|}{$1997-2002$} \\
\hline Growth in output & 2.57 & 7.69 & 3.16 \\
\hline \multicolumn{4}{|l|}{$2002-2007$} \\
\hline Growth in output & 5.48 & 12.20 & 6.58 \\
\hline
\end{tabular}

Source: presentation by Frank Veneroso, "China: Solow, Minsky", presented at the Hyman P. Minsky conference on Financial Instability, Debt, Deficits and Unstable Markets, organized by the Levy Economics Institute, November 26-7, 2012, in Berlin, Germany.

This exceedingly rapid growth has been enabled by an increase in production and consumption across a range of critical industries. China has succeeded not only at producing for export commodities that are labor-intensive in their production, but also has shown its ability to

\footnotetext{
${ }^{11}$ Data in the table above and the table below are taken from a presentation by Frank Veneroso, "China: Solow, Minsky", presented at the Hyman P. Minsky conference on Financial Instability, Debt, Deficits and Unstable Markets, organized by the Levy Economics Institute, November 26-7, 2012, in Berlin, Germany.
} 
quickly develop more sophisticated production techniques. ${ }^{12}$ To sustain development, China has undertaken "structural transformation", moving from low wage and low productivity output to higher wage and higher productivity processes. Jesus Felipe et al., (cited in footnote 12) examine China's increased sophistication and diversification of production as significant contributors to this transformation process. Given China's current GDP per capita, the level of sophistication of its output is considerable - and growing rapidly. And with regard to diversification, China also stands out - ahead of fellow BRICs Russia and Brazil, and even ahead of South Korea. In those respects, China is already more like a developed country than a developing country.

China's share of global totals of commodities output necessary for economic development is huge:

Table 2: China's share of global totals of commodities output

\begin{tabular}{|l|c|}
\hline Commodity & China \% of World \\
\hline Cement & $53.2 \%$ \\
\hline Iron Ore & $47.7 \%$ \\
\hline Coal & $46.9 \%$ \\
\hline Pigs & $46.4 \%$ \\
\hline Steel & $45.4 \%$ \\
\hline Lead & $44.6 \%$ \\
\hline Zinc & $41.3 \%$ \\
\hline Aluminum & $40.6 \%$ \\
\hline Copper & $38.9 \%$ \\
\hline Eggs & $37.2 \%$ \\
\hline Nickel & $36.3 \%$ \\
\hline Rice & $28.1 \%$ \\
\hline Soybeans & $24.6 \%$ \\
\hline Wheat & $16.6 \%$ \\
\hline Chickens & $15.6 \%$ \\
\hline PPP GDP & $13.6 \%$ \\
\hline Oil & $10.3 \%$ \\
\hline Cattle & $9.5 \%$ \\
\hline GDP & $9.4 \%$ \\
\hline
\end{tabular}

Source: Presentation by Frank Veneroso, "China: Solow, Minsky," presented at the Hyman P. Minsky conference on Financial Instability, Debt, Deficits and Unstable Markets, organized by the Levy Economics Institute, November 26-7, 2012, in Berlin, Germany.

${ }^{12}$ See for example Levy Working Paper No. 611, "Why Has China Succeeded-And Why It Will Continue To Do So", by Jesus Felipe, Utsav Kumar, Norio Usui, and Arnelyn Abdon, Asian Development Bank, Manila, Philippines, August 2010; forthcoming in the Cambridge Journal of Economics. 
It is no secret that this rapid development has required a shift from high consumption to high investment. The investment share in China's GDP is extremely high even by Asian standards, and has been maintained at a high level for a long time, as is shown in the following graph (figure 2). Note however, that one should not be misled by this chart. While consumption fell as a percent of GDP, per capita consumption grew quickly enough to raise living standards, reduce poverty rates, and create a growing middle class (as well as an elite class of wealthy households).

Figure 2: Investment and H/H Consumption as a Percentage of GDP

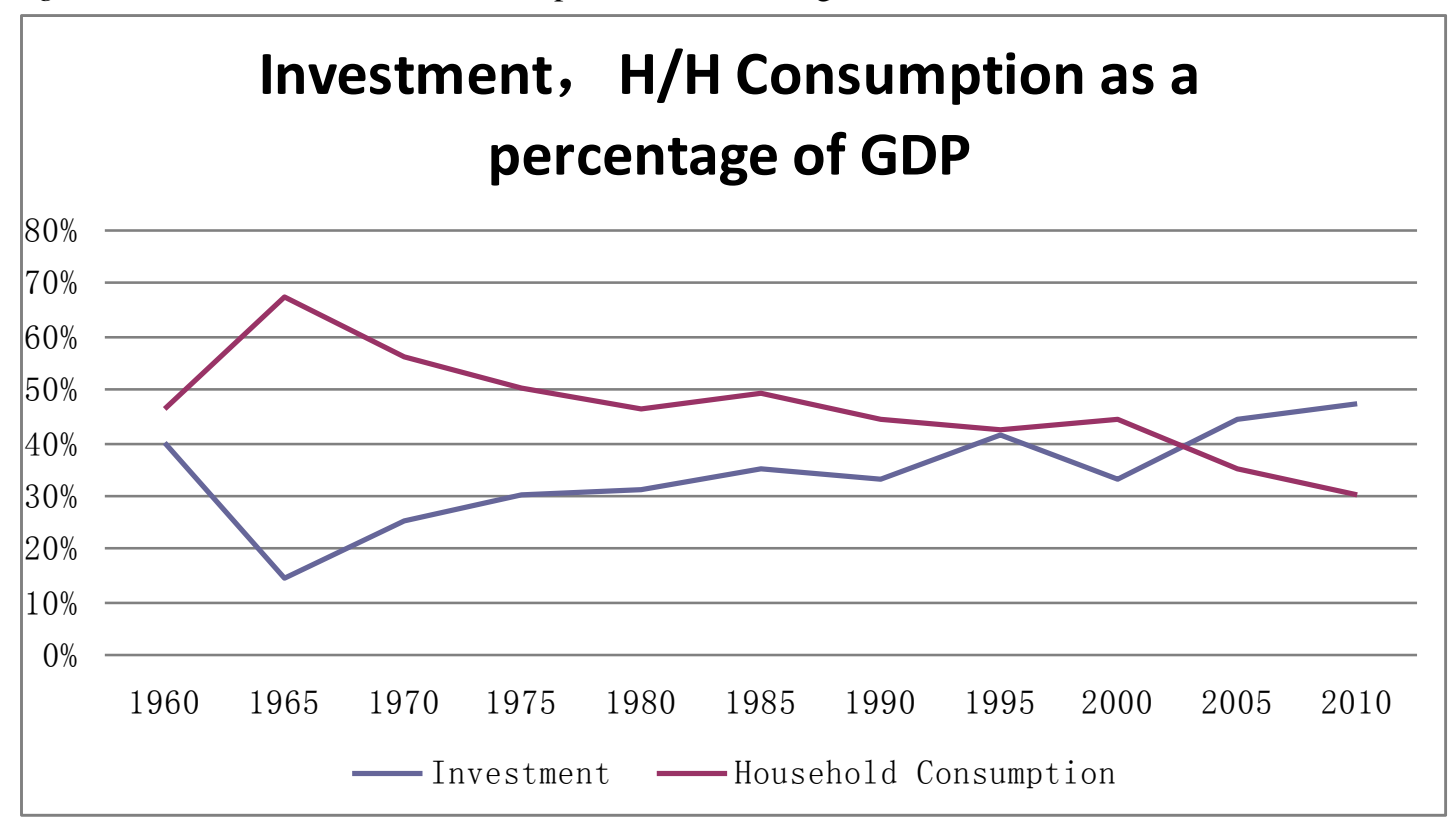

Source: China Center for Economic Research (CCER) database

China's long term global advantages were given a boost by US domestic policy, which focused on short run advantages rather than investing for the long term. As a result, China is poised to be a leader in many manufacturing areas-where its potential capacity accounts for a large portion of global capacity. China will remain a leader in the export of a range of manufactured products. At the same time, it is developing home markets and raising income. The challenge ahead will be to continue growth and rising productivity as the surplus rural labor force dwindles. (See the discussion that follows.) The alternative will be to accept somewhat slower growth - a topic to be discussed later.

However, large corporate debt burdens are easier to manage when growth is high, so lower trend growth could increase financial stress in the corporate sector. Relaxing the central 
government's budget is one way to help boost private sector finances. (This is also consistent with the sectoral balances approach of Wynne Godley to be discussed later.) Modest inflation also reduces debt burdens, although Western experience shows that excessive inflation comes at a political cost. A slow transition to less reliance on corporate debt to finance economic growth would reduce the dangers of financial fragility.

Liu Yuhui, director of the financial lab at the Chinese Academy of Social Sciences, was reported to say that most of the newly borrowed money now is used to repay debts instead of forming revenue among companies. He went on to argue that rolling over loans has become widespread as lending extended during the financial crisis to stimulate economic growth gradually came due but could not be paid back on time. It was reported by the China Banking Association that more than half of the 850 bankers surveyed said they support the practice of rolling over mature loans so long as interest can be paid, as this ensures projects have good cash flow. They expect that the loans will eventually be repaid following a grace period. Liu implied that banks are doing this instead of classifying the loans as non-performing assets.

In the classification scheme developed by Hyman Minsky, this would be called "speculative finance", where income flows can only service interest rates. "Hedge" is the safest position, where principal can also be repaid. He warned that a speculative position can become "Ponzi" if income flows fall or if interest rates rise-where interest has to be capitalized (borrow just to pay interest). This is the danger an indebted corporate sector faces when growth rates fall (or interest rates rise). Just how China might be able to transition to slower growth is complicated by heavy corporate debt. For that reason, the transition to slower growth needs to be carefully managed. One way is to have central government spending to lead growth in a manner that strengthens corporate portfolios - effectively by replacing corporate debt with central government debt. We will return to this argument later.

\section{Financial Sector: Banks, Shadow Banking, Wealth Management}

Liu Yuhui says, "We can see that the ratio of money to gross domestic product has been increasing, which means the economy needs increasing capital to promote than previously."13 Indeed, over the past year, bank and non-bank loans, and stock and bond issues set a record of nearly 16 trillion yuan ( $\$ 2.54$ trillion), with the M2 to GDP ratio reaching a record of $188 \%$.

\footnotetext{
${ }^{13}$ See http://www.chinadaily.com.cn/china/2013-02/28/content_16262459.htm
} 
The figures below show relatively rapid growth of the wealth management sector; however by contrast in spite of fairly rapid growth of loans by commercial banks, loan volume has just kept pace with GDP.

Figure 3: Number of WMPs Issued by Chinese Commercial Banks

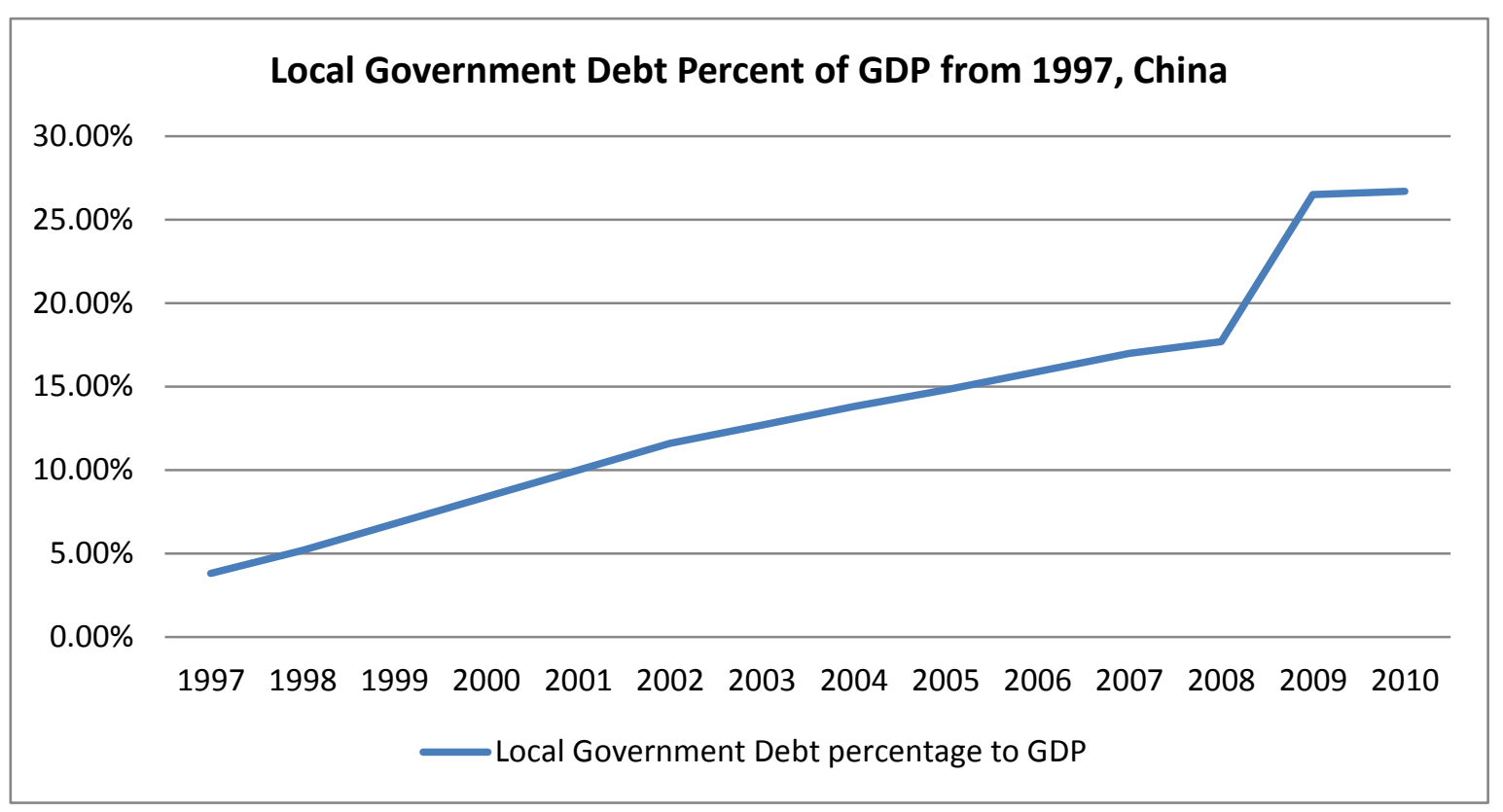

Source: Annual report on China's commercial banks finance development (2009-2010), Puyi Wealth 2011-2012 annual report of the bank financing market

In other words, traditional banks are not expanding at an abnormal rate, but the "shadow banking" sector is growing rapidly_much as the West's shadow bank sector grew much faster than commercial banking over the past two decades.

Although data are hard to obtain, anecdotal evidence indicates that figures 5 and 6 probably understate the relatively rapid expansion of shadow banking. So-called "wealth management products" (WMP instruments sold to high net worth investors) alone probably total to more than a quarter of the country's estimated $\$ 3.35$ trillion in non-bank lending. "To some extent, this is fundamentally a Ponzi scheme," Xiao Gang wrote in the China Daily. "The music may stop when investors lose confidence." ${ }^{\prime 14}$ A range of industrial companies also engage in shadow banking as a side business. This could be RMB 24.4 trillion worth, or nearly 50 per cent

\footnotetext{
${ }^{14}$ See http://www.chinadaily.com.cn/opinion/2012-10/12/content_15812305.htm
} 
of GDP. Sales of such instruments soared $43 \%$ in the first half of 2012 to an amount total outstanding U.S. \$1.9 trillion.

Figure 4: Commercial Bank Loans as a Percent of GDP

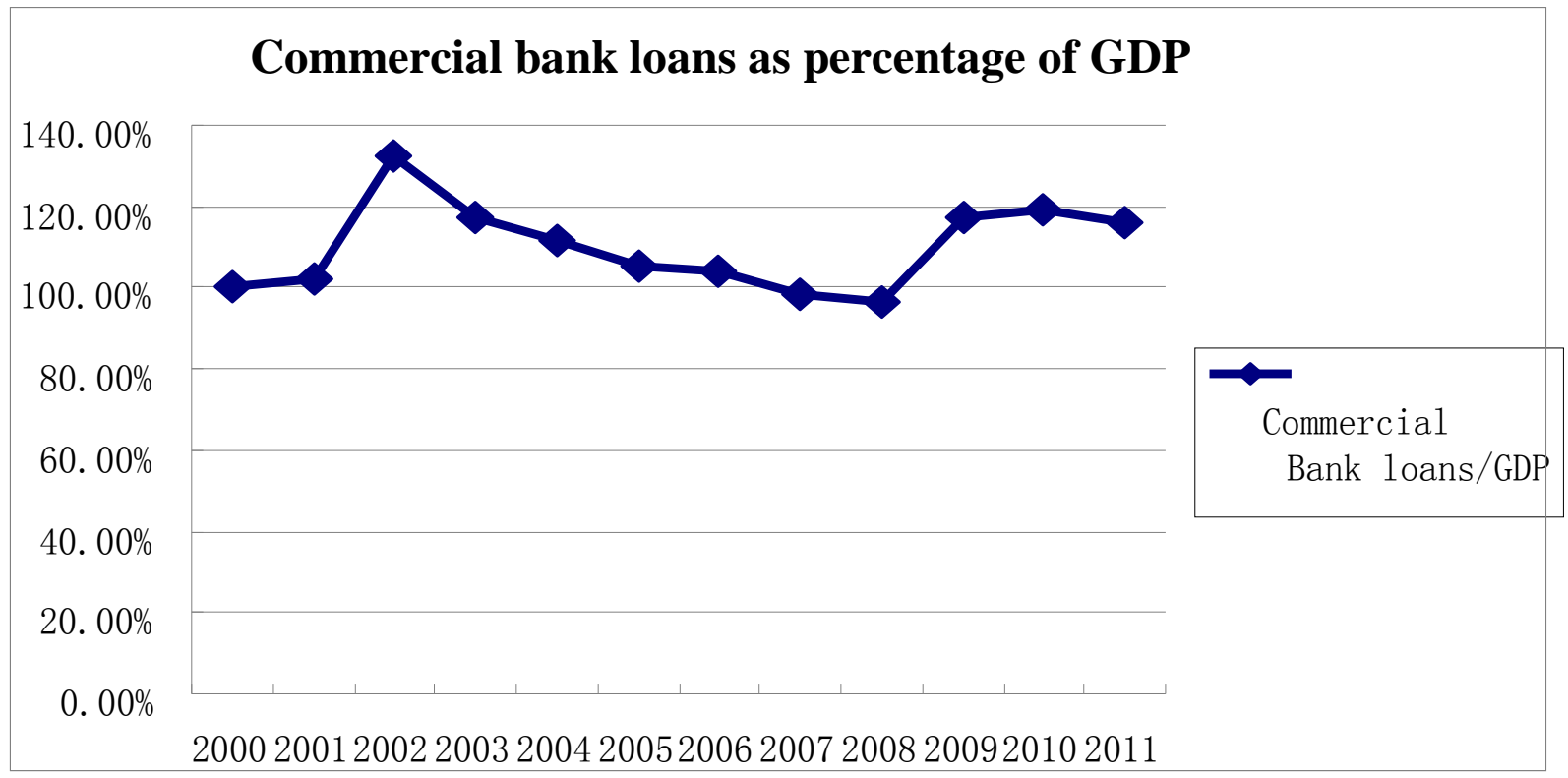

Source: China Center for Economic Research database

Figure 5: Commercial Bank Loans

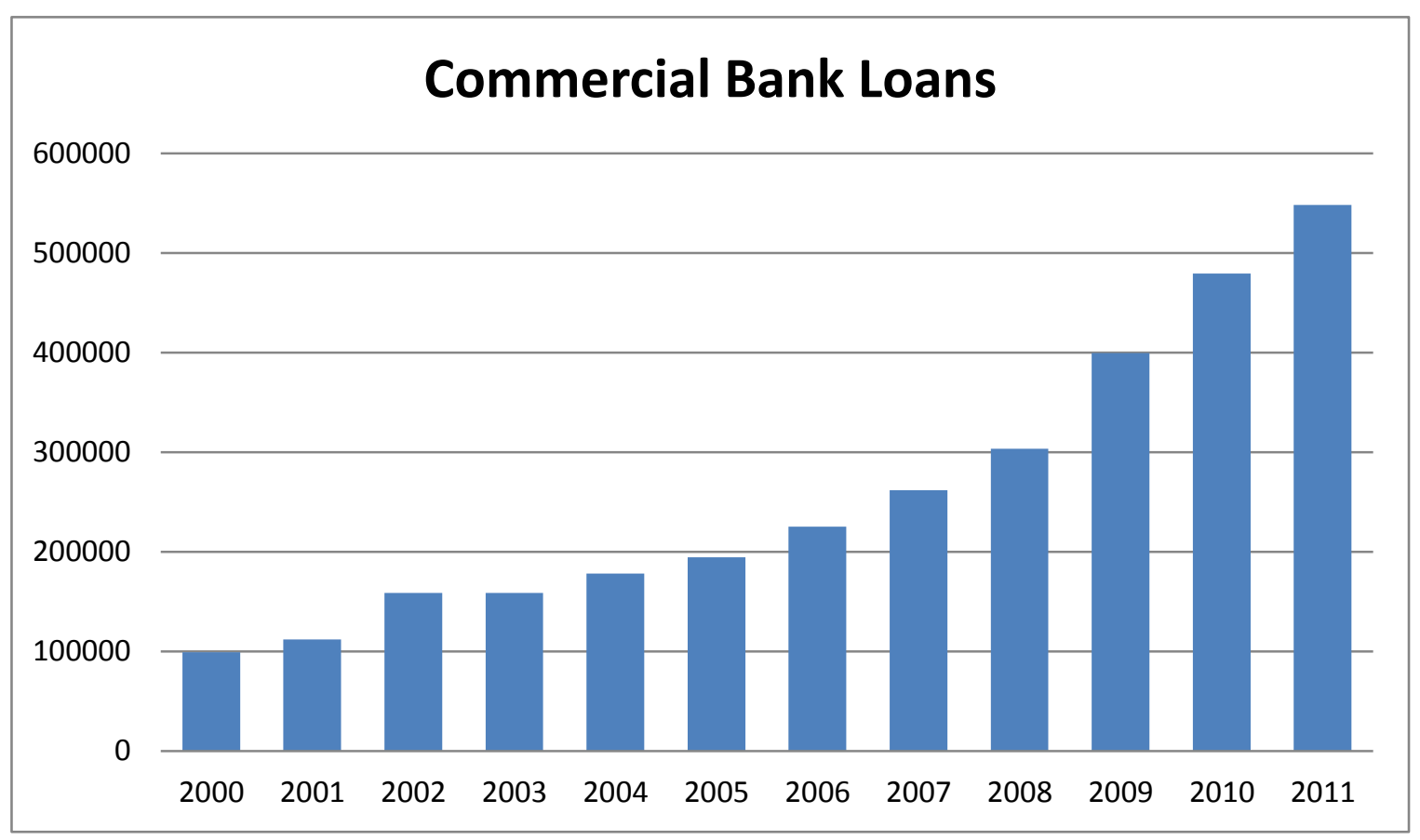

Source: China Center for Economic Research database 
As reported by Simon Rabinovitch ${ }^{15}$,

Shadow banking in China assumes various guises. The most basic are the illegal loan sharks who operate mainly in wealthy coastal regions, providing high-interest loans to small businesses that are often ignored by mainstream banks. But most of China's shadow banking is legal. The biggest of the non-bank institutions are trusts, companies akin to hedge funds. They cater to rich investors and promise high returns by lending to risky customers, especially property developers. A range of industrial companies, from shipbuilders to oil majors, also engage in shadow banking as a side business. Estimates about the size of shadow banking vary widely depending on how it is defined. Tying together various threads of official data, UBS economist Wang Tao believes it is no smaller than Rmb13.6tn ( $\$ 2 \mathrm{tn})$, or about one quarter of this year's gross domestic product, and could be as big as Rmb24.4tn, or nearly 50 per cent of GDP.

For all the difficulties of making a calculation, one thing is apparent: its rapid growth. Trusts, the backbone of the shadow sector, had Rmb6.3tn of assets under management at the end of the third quarter, up 54 per cent from a year earlier and five-times more than at the start of 2009. KPMG says trusts could surpass insurance this year as the secondbiggest institutional component of China's financial system, smaller only than banks. A senior commercial banker who worked as a regulator until last year says the complexity of the shadow products was also increasing. "It has begun to get to a degree like we saw in the financial crisis in the West. Products are being created that regulators don't fully understand, banks don't fully understand and customers don't fully understand," he says.

Figure 6: Value of WMPs issued by Chinese Commercial Banks

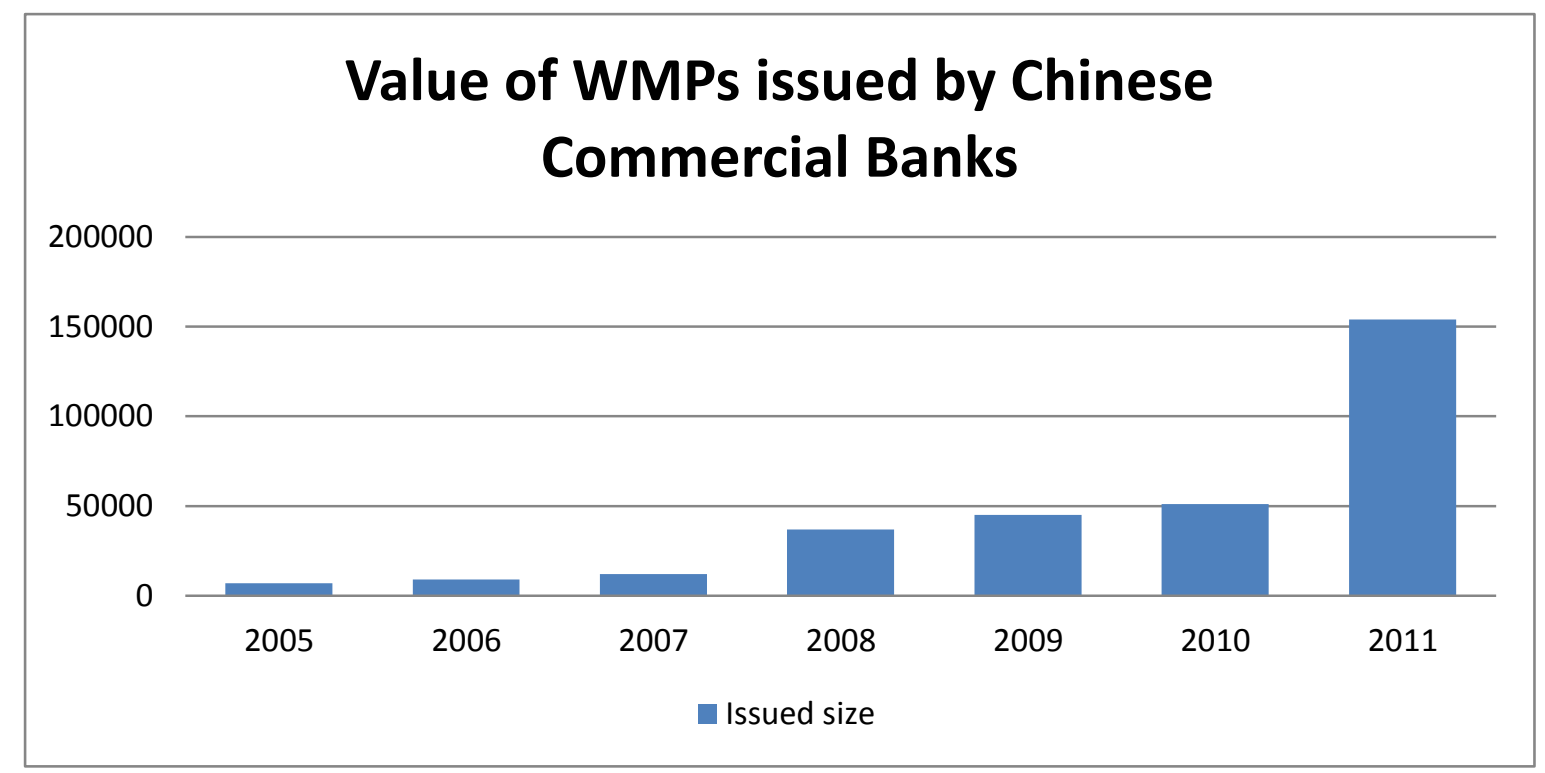

Source: Source: annual report on China commercial banks finance development (2009-2010), Puyi Wealth 20112012 annual report of the bank financing market

\footnotetext{
${ }^{15}$ Published in the Financial Times ( http://www.ft.com/cms/s/2/7070ccdc-3ade-11e2-bb3200144feabdc0.html\#ixzz2E4dXAic4)
} 
Of particular concern are the WMPs that are expected to exceed Rmb20tn this year. The Financial Times studied 50 WMPs and found that they generally did not disclose to borrowers what assets they purchase; indeed, only one of them fully disclosed its investments. For those who remember the United States investment trusts of 1929, China's WMPs sound eerily similar - vague statements about investments to be disclosed at a future date. (And recall that these investment trusts failed spectacularly after 1929; it was discovered that many of them were fraudulent, as discussed in John Kenneth Galbraith's The Great Crash.)

In addition to lack of transparency there are two other possible concerns. First, the rise of WMPs and shadow banking generally means that it has become harder for the national government to discourage lending in overheated sectors. While bank lending can be slowed, shadow banks (often lending at higher rates) come in to fill the credit gap created. Second, just as the United States discovered over the past 20-30 years, traditional mainline and relatively safe banking business cannot compete for funding with shadow banks willing to pay much higher rates to savers. The banks will feel pressure to make riskier loans in order to be able to afford higher funding costs. In the US, particularly, this led banking regulators to loosen rules to level the playing field - so that the activities of banks became very similar to those of the shadow banks. (This played an important role in creating the conditions that led to the global financial crisis.)

Moving forward, the rise of shadow banking raises important issues that need to be addressed with regard to regulation and supervision of financial institutions, including the decision whether to "level up" or to "level down" (tighten rules on shadow banks, or relax them on traditional banks).

\section{Local Government Finances}

Below we present detailed data on local government debt and deficits. The debt ratio has climbed above $25 \%$. Excluding fiscal transfers and tax rebates from the central government, local government deficits are very large and have climbed toward 9\% of GDP. However, after counting the funding from the central government, local government deficits are small. Note that there is some question about the accuracy of the reported local government debt-some have estimated that it could actually be as high as 70\% of GDP. This is because local governments seem to have moved debt off balance sheets to special purpose vehicles. However, 
even a debt ratio of $25 \%$ is high for a local government (in the US, high debt states typically have debt-to-state-GDP ratios of $15 \%$ or less). Unlike the central government's debt, local government debt is risky unless backed by the central government. Local governments are “currency users", not "currency issuers". Relying on local governments to finance growth could increase financial fragility. Further, the current practice of local government sales of land to obtain revenue might be unsustainable (land is fixed in quantity) and could support favoritism. That could be an important consideration in interpreting these "macro" data and in policy formation that warrants further study.

\section{Household Finances: Real Estate Bubble?}

Investment in real estate has also been climbing at least in some major cities - residential real estate investment alone is now accounting for $15 \%$ of GDP, as shown in the following chart.

Figure 7: New Residential Real Estate as a percentage of GDP

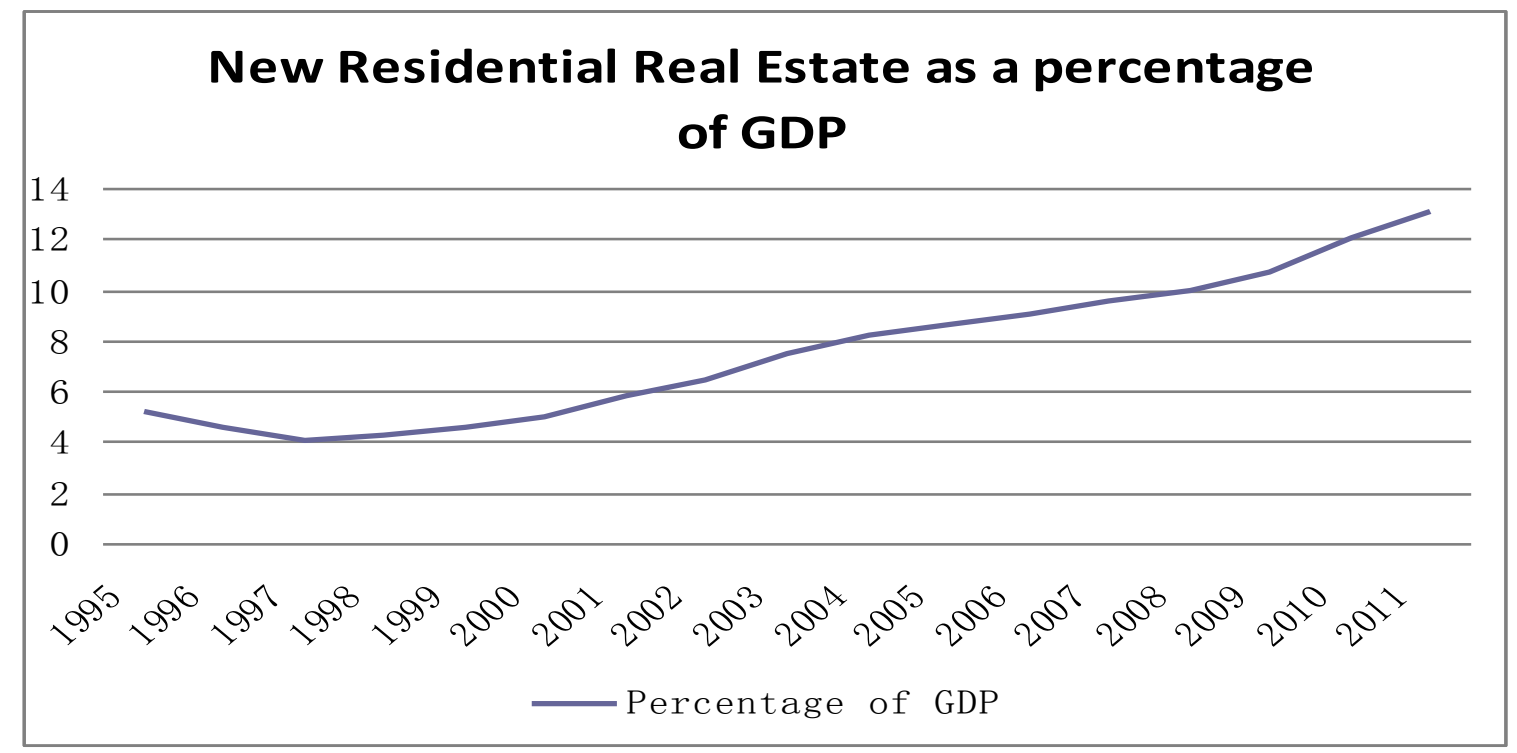

Source: China statistics year book, China Custom statistics, National Bureau of statistics of China

At the same time, real estate prices are booming, and prices in some Chinese cities relative to incomes match or exceed those in major world cities: 
Figure 8: Housing Price to Income Ratios in China

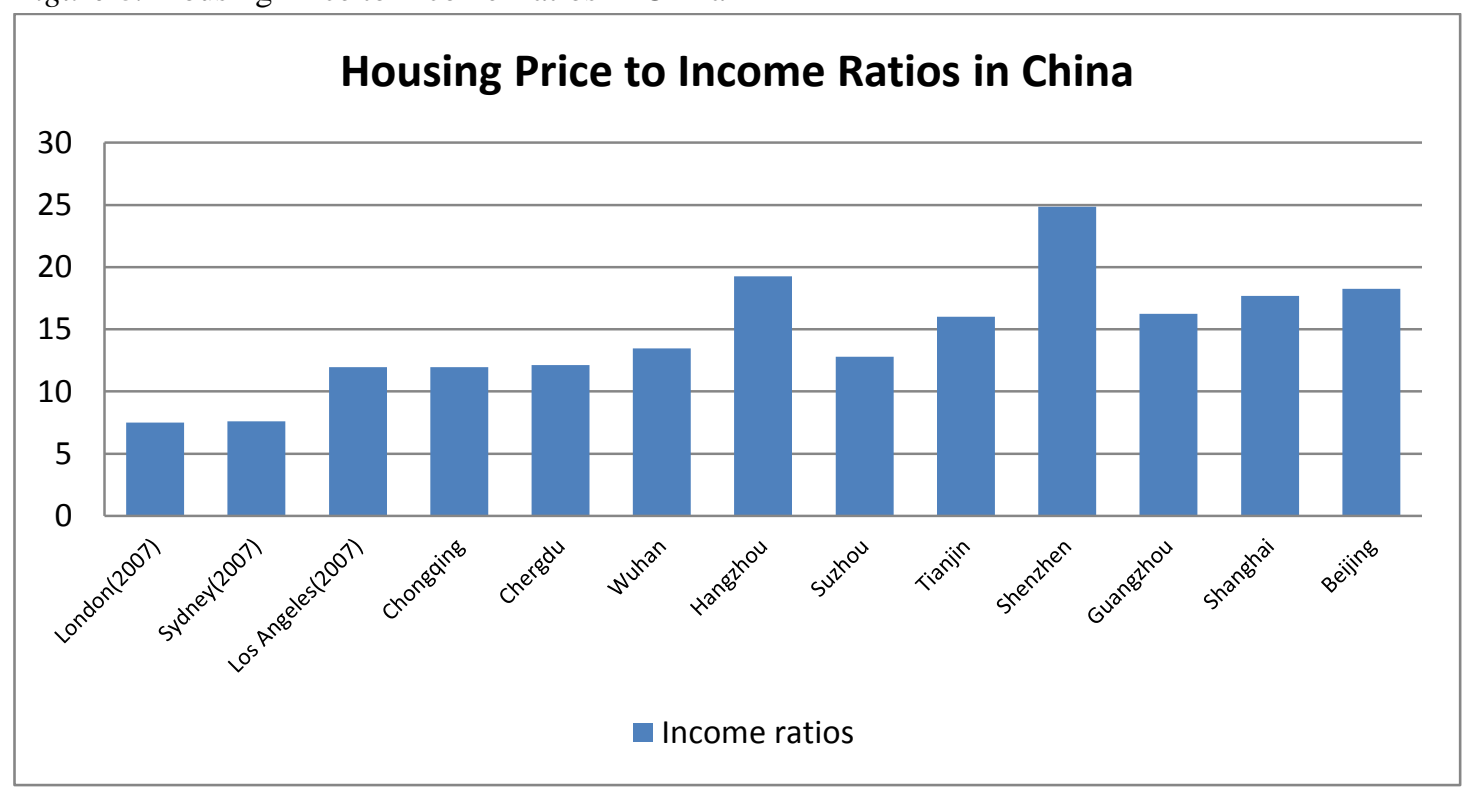

Source: Nomura Demographia Pivot

Many observers are worried about speculation in residential real estate in at least some cities. Anecdotal evidence indicates that households with rising incomes (due to robust economic growth) are looking for high returns on savings. Speculative purchases of housing are probably playing a role in the price boom — and at the same time are probably putting housing out of the reach of at least some residents of these cities. With some important exceptions (say, Manhattan, NY), what we observe in the West is that when prices rise too high relative to median income, a real estate bust occurs. Savers could lose substantial amounts of their savings. To attenuate the boom, China has imposed restrictions on house purchases.

At the same time, the rise of house prices-which raises the entry cost to speculating in housing - has pushed savers into the shadow banking sector to seek high returns there. Hence, these two phenomena are linked; and a vicious circle can be created when savings flowing to shadow banks help to fuel real estate prices as buyers access these funds.

The following graph (figure 9) shows stock values relative to GDP; although there was a "bubble" early, prices have returned close to 2000 levels. 
Figure 9: China stock market value to GDP from 2000 to 2011

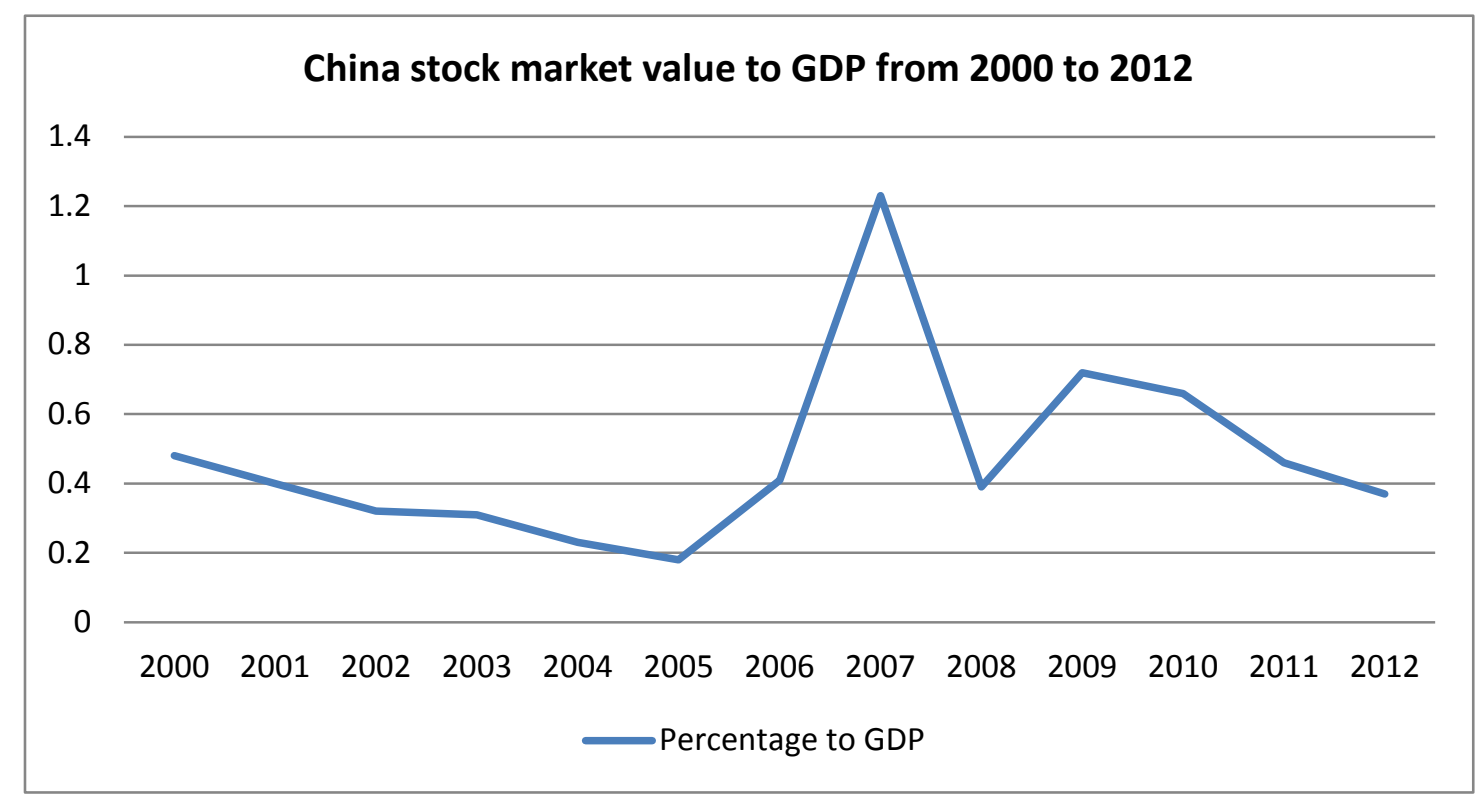

Source: China Center for Economic Research database

Perhaps the greatest concern today is the large increase of inequality since 1990, as the Gini coefficient rose from 0.32 to $0.47 .{ }^{16}$ The ratio of the income of the top $10 \%$ to the bottom $10 \%$ has increased by $15 \%$. There are several contributing factors to increasing inequality: the urbanrural wage gap (which has recently stopped rising), the education-related income gap (which is actually increasing), and differential access to nonwage income (profits, capital gains, and interest). Rising house prices, as well as speculative ownership of multiple housing units, is contributing to inequality. Although the government is trying to reduce such speculation, and at the same time plans to boost minimum wages for low income workers, more will have to be done to reverse the trend. Unfortunately, as we discuss below, social spending is currently far too small to offset "market" trends that work to the advantage of well-educated, urban, and especially coastal residents. Indeed, the Asian Development Bank (ADB) reports that local government spending makes matters worse: provision of public services is perversely skewed toward the richest counties (per capita public spending in the richest county is 40 times that in the poorest county). So not only does the central government need to overcome market forces but also local government spending that together tend to enhance inequality.

\footnotetext{
${ }^{16}$ Data on inequality come from the ADB, "Reducing Inequality in the People's Republic of China through Fiscal Reform, No. 2013-3.
} 
Inequality can be socially destabilizing, but it can also be financially destabilizing. The precarious situation of poor households can lead to necessitous borrowing, often in informal financial markets at ruinous interest rates. At the other end of the income spectrum, wealthier households have the means to engage in speculation, creating bubbles that can quickly increase prices and then suddenly burst. Relatively well-off households seek high returns in informal markets - supplying the funds that are loaned at high interest to poorer families, farmers, or small businesses. Rising inequality seems to help fuel growth of the financial sector, perhaps at the expense of "industry". Some analysts have argued that the GFC resulted at least in part from growing inequality, growing "financialization" of the economy, and relative stagnation of real wages in the US. While China's situation is different, there could be some similar analogous relations between growth of "shadow banking" and rising inequality—with a potential for financial instability.

\section{Prospects for Growth: Will China Escape the Middle Income Trap?}

China's growth seems to have slowed in recent quarters. Is it too early to predict that China will fall victim to the middle income trap? China's GDP per capita has tripled since the late 1980s and is expected to triple again by the early 2020s. Even if growth is a bit slower than it has been, it seems inevitable that by the simple math of compound growth that China will avoid the trap.

Felipe argues that it is not likely that China will grow as fast as it has in the past, rather, it will eventually slow to a rate of perhaps $5 \%$ per year. ${ }^{17}$ That is still sufficiently fast to push the nation beyond the trap (since population growth is slow). Further, he argues that growth targets, alone, are not even desirable. China is already beginning to worry about environmental sustainability - a topic beyond the scope of this paper. And high growth could be fueling inequality, which is probably not socially sustainable, or at least it is not socially desirable.

In a series of pieces George Magnus ${ }^{18}$ has looked at limits to growth facing China. He follows Paul Krugman in arguing that the Asian "miracle" was not a miracle but rather can be attributed to organizational and institutional efforts to deploy labor and capital more

\footnotetext{
${ }^{17}$ Jesus Felipe, ADB Working Papers. "Tracking the Middle-Income Trap: What is It, Who is in It, and Why? Part 1". ADB Economics Working Paper Series, No. 306, March 2012, http://www.adb.org/publications/trackingmiddle-income-trap-what-who-and-why-part-1, and "Tracking the.......Part 2", ADB Economics Working Paper Series No. 307, March 2012, http://www.adb.org/publications/tracking-middle-income-trap-what-who-and-whypart-2. In this series, Felipe argues it will be difficult to maintain Chinese growth rates as high as they have been in the past.

${ }^{18}$ See note 4.
} 
efficiently. ${ }^{19}$ But China is now slowing because it has a) exhausted its demographic dividend (the "one-child" policy has slowed labor force growth), b) already completed much of the migration of labor from low productivity agricultural use to higher productivity urban production, c) raised educational standards substantially, d) reached maximum saving and investment ratios that are probably unsustainable, and e) already substantially opened its economy. He also argues that there are dangerous imbalances (some explored above), such as too much private credit (especially that used to finance investment), reliance on relatively inefficient state owned enterprises, high income inequality, and suppressed factor prices. In conclusion, he recommends reducing the role of the government and increasing the role of markets. China's growth will slow to $4-5 \%$, and he predicts that will bring down growth of the rest of developing Asia; this will compound the problems created if the West continues to grow slowly. Magnus argues that of 52 identified middle income nations, 35 got trapped and another 8 are likely to also get trapped. He examines a list of factors that make falling into the trap, and argues that many of these do fit China's situation.

Felipe et al., (2010) is less pessimistic. China joined the upper middle income group in 2009, after having spent only 17 years in the lower middle income group. It can make it to the next group as soon as 2015 even if it grows at only $5 \% .{ }^{20}$ Further, Felipe argues that rather than shifting emphasis from government to free markets, the best strategy is for government to work to organize key private players, to encourage cooperation and joint projects. He concludes that China is actually in a good position to continue with its development strategy, but with less focus on growth as the important policy goal:

"China is implementing policies to achieve a "harmonious society". Chinese policymakers have realized that solving problems such as unemployment and underemployment, a deteriorating environment, or increasing inequalities, will determine how well the country does in the next decades. Perhaps policymakers should think less in terms of a growth target and more in terms of employment creation (and unemployment/underemployment reduction) and structural transformation targets. Growth will be a by-product. Development is a path-dependent process and China has acquired tremendous knowledge and competency that will allow it to continue thriving in the next decade." (Felipe, et.al, 2010, p. 42)

\footnotetext{
${ }^{19}$ See also Felipe et.al., 2010 and Felipe 2012, cited in notes 12 and 17, respectively.

${ }^{20}$ Felipe ADB working papers, cited above.
} 
To sum up: it is likely that China's growth will slow, but the nation will continue on its path to join the developed high income group. By turning to face other issues, China can tackle the problems discussed above. Let us turn to current policy formation and then move to recommendations.

\section{Quick Overview of Current Policy Making in China}

\section{Monetary Policy}

Since July 2005 China has maintained a managed exchange rate regime, with small and rather infrequent changes to its managed rate. Officially the government targets a basket of currencies but it has not announced which currencies nor the weights used to construct the basket. Goodfriend and Prasad (cited in footnote 9) concluded that the managed rate looks like it is pegged to the US dollar. Large current account surpluses have allowed China to accumulate massive foreign exchange reserves, the majority of which are dollar claims. China also operates with constraints on capital flows, however rising speculative flows (including those from Hong Kong) could make it more difficult to maintain the managed exchange rate; continued slow growth in the West can also reduce net exports and it is conceivable that the trade account could turn around in the not-too-distant future. While exchange rate adjustments have led to a stronger currency, it is not clear which way the balance of forces might eventually trend-even if a trade deficit were to emerge, capital flows into China would probably relieve at least some pressure on exchange rates.

Dollar inflows are "sterilized" by the central bank. In conventional thinking, this is necessary to prevent inflows from increasing bank reserves and thus the domestic money supply. Private banks receiving dollars would exchange them at the central bank for domestic currency reserves. According to the deposit multiplier argument, banks would then expand loans and deposits by a multiple to absorb excess reserves. Hence the central bank engages in an open market sale of bonds to remove the reserves. In most countries, the central bank sells treasury debt. 
However, today's modern central banks operate with an overnight interest rate target (the fed funds rate in the US, for example), not with a target for money supply. ${ }^{21}$ If a current account surplus increases a bank's reserves, this puts downward pressure on domestic overnight rates that is relieved by an open market sale of government bonds. Given that the central bank targets rates, there really is not a choice whether to sterilize - the consequence of not sterilizing undesired increases to bank reserves is that the central bank will normally miss its target interest rate (things are a little more complicated if the target is zero-so-called "ZIRP" or zero interest rate policy — or where the central bank keeps rates between a band by paying, say, 25 basis points on reserves and charges 50 basis points to lend reserves, because in both cases reserves can be left in the system).

With this background we can examine the case of China's monetary policy—which is rather more complicated than what we find in the West. Goodfriend and Prasad argue that China only partially sterilizes the inflow, which can threaten its attempt to target money supply growth. Further, as discussed above, there is not much government debt, so the PBC issues bills to drain the excess reserves. In addition the government pays interest on excess reserves (note that this has become more common in the West, with the Fed starting to pay interest on reserves once the GFC hit the economy and the Fed's liquidity provision in response caused reserves to grow rapidly to unprecedented levels). So the questions are: what is the Chinese central bank targeting? Do foreign currency inflows complicate monetary policy? And, is it possible to simplify monetary policy operations?

The PBC has a mandate of "maintaining the stability of the currency, and thereby promoting economic growth" and also a mandate to maintain financial stability that is not explicitly stated. A Monetary Policy Committee meets quarterly to set the framework for policy implementation. The PBC uses open market operations (mostly involving PBC bills), selective transactions (discount window lending), required reserve ratios, interest rates (on bank loans and deposits), credit controls, and other means of regulation. Hence, unlike the case of the developed countries in the West, the PBC makes use of a broader array of tools to implement

\footnotetext{
${ }^{21}$ The old Monetarist approach to monetary policy targeted reserve and money supply aggregates based on the notion of a "deposit multiplier". It is now widely recognized that this approach was always flawed. The deposit multiplier is more correctly thought of as a "divisor"-given the quantity of deposits created in loan-making activities, this divisor tells the bank how many reserves it must hold. In practice, central banks accommodate that demand. See Wray, Modern Money Theory, cited above.
} 
policy. In the West, the main tools are open market operations (in treasury debt, usually) and changing the target interest rate (overnight interbank lending rate and discount window lending rate). Chinese banks typically hold excess reserves (on which they earn interest), perhaps because the $\mathrm{PBC}$ changes the required reserve ratio much more frequently than do central banks in the West. Further, it seems that Chinese banks really do respond to increases of required reserve ratios by reducing loan expansion - as they try to comply with PBC intentions.

By contrast, in the West private banks normally do not operate with excess reserves (the period since the GFC is a glaring exception), and raising required ratios simply forces overnight market rates above target, triggering open market purchases by the central bank to provide required reserves. If monetary policy tightening works, it does so through interest rate effects.

So it is not clear that dollar inflows complicate PBC policy making at all—banks willingly hold excess reserves if the PBC does not fully sterilize. The $\mathrm{PBC}$ signals its intention to tighten policy by raising required reserve ratios, by tightening credit controls, and by using other regulatory means. It is in this sense that one can rightly say that the PBC uses "extra market" tools to implement policy.

Further note that as the PBC pays interest on excess reserves it really does not need to use its bills to sterilize reserves created by dollar inflows in any case. Operationally, PBC bills are longer maturity reserves that pay interest — sort of like savings deposits at the central bankperhaps a higher interest rate than what is paid on excess reserves. Looked at from that perspective, there is no operational difference between sterilizing and not sterilizing except that the first might increase bank interest earnings over the second. The belief that the first leaves the PBC with more policy space than the second seems erroneous.

The claim that the PBC's latitude for monetary control because of "financial repression" (low interest rate policy) might have more validity. Much like the case of the US in the early postwar period, China restricts bank lending and deposit rates (in the US this was done both through public law_-"Regulation Q" as well as "usury laws"-and through an informal Fed commitment to keep rates low even after the famous Treasury Accord of 1951 that increased monetary policy independence). However, in China, there is the additional concern that if deposit rates were free to move higher, capital seeking higher returns would probably flow into China. 
Some, like Goodfriend and Prasad (cited in footnote 9), believe that the PBC keeps deposit rates low so that commercial banks have a cheap source of funding, which in turn allows the PBC to pay low rates on its own bills (held by the banks as assets). If deposit rates rose, the banks would have trouble maintaining profitability unless the $\mathrm{PBC}$ raised the rates it pays. In addition, there is a long history of literature on financial repression that asserts low interest rates discourage saving and hence bank intermediation. The "repressed" banking system supposedly remains primitive and unable to finance sufficient investment.

There are additional criticisms raised in support of the argument that the low interest rates misallocate resources. For example, the low deposit rates provide cheap finance to banks that are carrying a lot of the debt of state owned enterprises (SOEs) that are said to be unviable. At the extreme, imagine that a bank pays zero interest on deposits and holds nonperforming loans to enterprises that cannot make any interest payment. The "zombie" firms and banks can stay in business hoping for a miracle. The argument is that letting rates rise would move capital to better uses because the "zombies" would be driven into bankruptcy.

Yet, as discussed above, China's investment ratio has long been sustained at a nearly unprecedented level - there seems to be no lack of "capital" to allocate to new projects. Second, there is a burgeoning shadow bank sector (with the commercial banks heavily involved) with much higher loan and deposit rates. To be sure, this raises many important questions and concerns as briefly discussed earlier. But the problem is probably much less one of "financial repression" but rather one of excessive innovation, speculation, and off-balance sheet activity that is escaping proper regulation and supervision and thereby increasing financial fragility. Bringing that back into the regulated banking sector is probably desirable, but it is not clear that raising interest rates in the commercial banking sector is the answer. Indeed, the US essentially followed that path by first deregulating interest rates to allow the regulated banks to compete, and then by deregulating banking activity. The result was to spread risky and ultimately disastrous financial practices all through the entire global financial system. We'll return to policy recommendations later in this report.

To conclude this section's assessment of current monetary policy formation, let us consider the implications of two alternative policy targets. The PBC currently follows a policy of targeting money and credit growth. Like western countries that tried to target monetary aggregates (most notably in the late 1970s in the UK and the US, which adopted Milton 
Friedman's rules-based policy), China is finding that the link between money supply measures and GDP is breaking down. To put it the way economists do, "velocity" is not stable (the quantity equation identity shows that the money supply times velocity equals the price level times a measure of real output; this can also be put in a dynamic form so that if velocity is stable, and if real output grows at capacity - say, 4\% - then inflation results when the money supply grows faster than real output). In China's case, velocity has been falling-which means that the money supply growth rate is above the rate of growth of output. With an unstable velocity, hitting a money growth target might not provide the rate of economic growth desired. This unstable velocity is the main reason that most western nations abandoned monetary aggregate targeting.

Some western nations have moved to inflation targets. These typically adopt some version of a Taylor Rule. To simplify, this is the notion that the central bank adjusts its policy interest rate in response to output gaps and inflation outcomes (current and expected). (A recent Hong Kong Monetary Authority paper explicitly models such an approach. ${ }^{22}$ ) This seemed to work well before the GFC in the sense that the West enjoyed a relatively long period of low inflation. However, that seems to be just as true of nations that did not adopt inflation targets (including the US) as of those that did. We will not enter that debate here. The bigger problem is that the policy does not appear to be working in the aftermath of the crisis, as many western nations cut rates (some essentially to zero) without halting a trend toward outright deflation or at least toward inflation rates below target. In other words, at best this policy is asymmetric - it might work when growth is robust but it does not work in a downturn.

The alternative is to target interest rates in a more flexible manner to achieve reasonable growth and low unemployment without excessive inflation. This has been the US model since it abandoned monetarism in the 1980s, and indeed this was the informal approach long used in the US and elsewhere before the monetarist experiment. In a sense, the claims made for its efficacy are rather moderate. For much of the postwar period, it was believed that a nation must use both fiscal policy and monetary policy to achieve its economic goals. The experiment in monetarism was a deviation from that trend, and the elevation of monetary policy above fiscal policy in the

\footnotetext{
22 "Monetary stance and policy objectives in China: a narrative approach", Chang Shu and Brian Ng, China Economic Issues, Number 1/10, January 2010, Hong Kong Monetary Authority. 
decades that followed now appears to have been a mistake. As discussed above, fiscal policy seems to have been resurrected as a viable policy tool.

Before moving to fiscal policy it is useful to discuss one more issue related to central banking. As a result of its trade surpluses, China's central bank has accumulated a large quantity of foreign currency, much of it in the form of dollar-denominated assets (of which US Treasuries account for most of them). Since there are pressures on the exchange rate (for the $\mathrm{RMB}$ to rise relative to the dollar), there is a potential for the PBC to suffer capital losses. This, in turn, is a justification for internationalizing the RMB and for reforming the global financial system in a manner that reduces exposure to losses from dollar depreciation.

If China could denominate more of its trade in $\mathrm{RMB}$, it would receive fewer dollars in return for exports. This is true and will almost certainly occur, although how important it will be for even the medium term (say, the next decade) is far from certain. A big part of the reason that the dollar dominates in the international flow of traded goods and services is because dollardenominated assets are desired in portfolios. Indeed, the "capital account" transactions in dollars exceed by many orders of magnitude global flows related to current account. One could even argue that the desire to run current account surpluses by many of the exporting nations is to accumulate dollar reserves. There are a variety of reasons for this: the dollar is a relatively stable currency (both in terms of inflation and exchange rates); the US is a large and relatively stable economy; US political and legal institutions are perceived to be relatively transparent and trustworthy, and so on. (See Eichengreen $2013^{23}$.) Certainly all of that can change, and China is moving in a direction that will eventually increase the demand for its RMB-denominated financial assets.

There is another key condition: for a currency to become internationally important, the rest of the world must be able to obtain it. The two main ways to get a foreign currency is through sales (exports) or borrowing. The US purchases a large volume of net exports and it also lends dollars, so the dollar is relatively easy to get. Some years ago, there was a lot of talk of the euro replacing or at least supplementing the dollar. After all, the European Union's economy is even bigger than the US economy, and its institutions are also stable and trustworthy - and its currency was appreciating. The problem was that the euro is relatively hard

\footnotetext{
23 "Renminbi Internationalization: Tempest in a Teapot?", Barry Eichengreen, January 2013; ADB Distinguished Lecture, delivered in Manila, January 11, 2013.
} 
to get - the most economically powerful member, Germany, runs large trade surpluses, and the EMU zone runs small surpluses against the rest of the world. So to obtain euros means borrowing them. It is not unprecedented for the issuer of an international reserve currency to lend them into existence (London was the world's banker), so that it is conceivable that a nation could be a net exporter and still provide an internationally important currency. However, if nations prefer to obtain foreign currency reserves through net exports, and given that the dollar is already dominant in global portfolios, it will be hard for another currency to displace it.

Returning to the fears about capital losses on the PBC's balance sheet should the RMB rise relative to the dollar, we need to recognize that these are "paper losses" that are easily absorbed by a sovereign currency issuer. As we'll discuss in more detail, there is no "financial solvency constraint" imposed on the sovereign government - which cannot be forced into involuntary default on its commitments. No matter how much the government's portfolio of foreign currency assets falls relative to the domestic currency, the sovereign will not be forced to miss promised payments in its own currency. Further, as the RMB rises in value relative to the dollar, imports become cheaper in terms of RMB. At least some of the "paper losses" are offset by gains in the purchasing power of the domestic currency. Since the Chinese government spends RMB, losses on dollar holdings do not impinge on its ability to spend. Indeed, if cheaper imports reduce inflationary pressures, the central government can spend more without fueling inflation.

None of this should be interpreted as arguing against internationalization of the RMBor of reforming the global monetary system. However, it does remove one argument for moving in that direction - the fear of losses on the PBC's portfolio.

\section{Fiscal Policy}

As we will discuss below, China's central government receives the largest share of tax revenue, leaving local government heavily dependent on fiscal transfers, tax rebates, and land sales. China's tax system is relatively regressive as it relies on the VAT. Further, the tax system is biased in favor of manufacturing over services. ${ }^{24}$ Social spending is small in comparison with other middle income countries. For example, government spending on health care is just $1.4 \%$

\footnotetext{
${ }^{24}$ Source for information on taxes and social expenditures: ADB, "Reducing Inequality in the People's Republic of China through Fiscal Reform", No. 2013-3.
} 
of GDP, versus the Organisation for Economic Co-operation and Development (OECD) average of $6.5 \%$. Total spending on social security, education and health care equals just over a third of government revenues or just 9\% of GDP. By contrast, the other middle income countries devote over $50 \%$ of expenditures to social spending. Social spending averages $20 \%$ of GDP in OECD nations, and 15\% of GDP in Brazil and Russia. We will discuss recommendations for fiscal policy reform below; in the remainder of this section we will focus on fiscal operations.

From 2001, China has adopted the "Treasury single account system", which includes five different sub-components. ${ }^{25}$ The system was designed to centralize government spending and help to improve fiscal policy efficiency. The five components are:

1. The treasury maintains a single account at the PBC;

2. The treasury opens a "zero balance account" in each of the designated commercial banks, which is used for treasury spending (crediting accounts of recipients of government expenditures) but that cannot be used for cash withdrawal. This account is for direct government spending to its payee account that should be used by the end of day or month (this is why it is called a zero balance account). The treasury writes a check or sends an order to its designated commercial bank to credit money to its payee and then at the end of day clears the transactions using the treasury's single account at the PBC using reserves. The prohibition on cash withdrawals is supposed to guarantee that the money goes to the payee without being diverted by someone. The spending through this account mostly includes wages, engineering procurement spending, and goods and services expenditures for procurement.

3. The treasury opens a "zero balance account" in one of the designated commercial banks for different units (here units mean economic bodies included in the government budgetary spending system) that receive budgeted funds. Deposited funds can be withdrawn as cash. To explain, in the case of large allocations of funds, this can be done only be transferring reserves, but if the amount is lower than RMB 50,000, then the payee can withdraw cash. (In China, some government payments can be received in cash while some cannot. For example,

\footnotetext{
${ }^{25}$ Reference: Yan Zhou, "The Analysis On Treasury Account System In China”, Journal of Financial Management Cadre Institute in Fujian, 2003 (1), pp48-53.
} 
wages paid to university teachers can only be transferred to a bank account--the university cannot withdraw cash from banks to pay their employees by cash.) The difference between this account and the one described above in \#2 is that this one only requires an authorization from the treasury at the beginning, when the spending occurred. (For example, if a university has an annual budget of RMB100,000 provided by the central government, it can send a budgetary request to the treasury at the beginning of the year, and once approved, the university can draw down funds over the year.) The spending on this account includes some sporadic spending not included in $\# 2$.

4. The treasury opens an extra-budgetary account in one of the designated commercial banks for government spending. This account is used for receiving and spending funds that were not budgeted--for example, local governments or universities receiving unplanned fees. A university might receive more income from its training program that can be spent without a budgetary allocation by the treasury; however, these receipts must be booked in this account and must be supervised by the treasury.

5. The treasury also opens special accounts for specific spending programs such as earthquake funds, and other special needs arising from local governments or firms.

The treasury's single account at the PBC is the final clearing and settlement account for the other four accounts in the designated commercial banks as enumerated above. The accounts in commercial banks are the channels for government payments to be received by payees, out of the treasury's single account at the PBC. That is to say, if the treasury spends, its reserve account in the PBC is debited and the reserve accounts in the designated banks are credited by the PBC.

In general outline, these fiscal operations are similar to those in the West, and indeed the 2001 reforms might have been undertaken to model Western practices. In effect, the treasury and central bank use the commercial banks as intermediaries to make and receive payments. We'll turn to the implications of this later. For now it is sufficient to note that recipients of government payments receive credits to their bank accounts, and that payments made by them to government (for example, tax payments) result in debits to their accounts. Acting as intermediaries, the commercial banks receive credits to their reserve accounts at the PBC when 
government makes payments through them, and their reserve accounts are debited whenever their customers make payments to government. Government budget deficits, all else equal, will lead to net reserve credits and budget surpluses lead to net reserve debits.

When the treasury sells government bonds, these are purchased by commercial banks whose reserves are debited. If the PBC engages in an open market sale of government bonds, the impact is the same: reserves are debited. When the PBC buys government bonds from banks (or from their customers), reserves are credited. As discussed above, PBC bills are more important than are treasury bonds for the implementation of monetary policy and as well to sterilize foreign currency inflows. Treasury debt is quite small relative to GDP. Below we will investigate the implications of this for macroeconomic balances.

However, some fear that off-balance sheet contingent government liabilities are so large that they pose a threat. We have no estimate of the size of these liabilities. If we assume that much of the corporate debt has been issued by SOEs and that the national government will come to the rescue of these firms (that is, making bad debt good), then potential liabilities could be as much as a hundred percent of GDP—or perhaps even more. It is unlikely that all of this debt would go bad, but there are also the state bank liabilities (the two are linked because failure of

an SOE would impact banks - however, making bad loans good would at the same time help the banks).

The question is this: would China's national government be able to absorb these liabilities, perhaps significantly increasing its government debt ratio, without calling into question government solvency? This is a question we cannot address satisfactorily until we examine the theory of sovereign currency in some detail. The following sections provide the background necessary to understand the issue.

\section{IMPLICATIONS OF FIXED EXCHANGE RATE SYSTEMS}

\section{Introduction: China's Exchange Rate System}

Many developed countries, especially the US, have tried to push China to appreciate its currency both before and after the global financial crisis. This is in part because they believe that the trade imbalance was a main cause for the deep global recession. China had more than $\$ 3$ trillion in foreign reserves which supposedly in turn were recycled into (mostly) US financial markets, pushing down the long term real interest rate and inflating asset prices in America. The 
Chinese government on the other hand resists appreciating its currency and instead has called for reformation of the international monetary system, and even has advocated movement toward something like Keynes's "bancor"- an international currency delinked from any particular country and used for clearing accounts among nations (discussed briefly below). Hence some believe that creation of a supranational currency would help China to maintain its fixed exchange rate regime as well as decrease the risk of its foreign reserves in the form of some special currency. Some believe the US tries to depreciate the dollar by "beggaring thy neighbor" through implementing QE2, and also claim the US Fed wishes to raise inflation expectations. These actions, in combination with lowering interest rates, could make America a less attractive investment option. And lower dollar values would increase US competitiveness in traded goods and services and this could boost exports and depress imports.

As we argue below, currency sovereignty implies the ability of a country to implement monetary and fiscal policies independently. However, this can be contingent on a country's adoption of floating exchange rates. China now has its own sovereign currency with a managed exchange rate, which could eventually attenuate its currency sovereignty to some extent. This is because the constraint of a fixed exchange rate system impels China to stockpile foreign currency reserves sufficient to keep the Chinese currency's value stable, which eventually could force fiscal policy to depress domestic demand. Hence, pegged exchange rates remove an important degree of freedom, holding domestic fiscal and monetary policy hostage to the exchange rate. We do not mean to overemphasize any dangers for the foreseeable future. China's currency reserves are huge, and her advantages in some export sectors are strong. Eventually, however, China will need to transition to greater exchange rate flexibility.

We argue that countries that have their own currency with a floating exchange rate, can afford anything in sale for domestic currency, so they don't actually need to rely on an export surplus to be achieved through dollar depreciating. Indeed, a "beggar thy neighbor" approach would not be beneficial for a sovereign country or for the world. Instead, achieving domestic, internal stability should be the primary goal of policy, with full employment and rising living standards (broadly measured) the most important domestic policy objectives. We conclude by pointing out some of the advantages of floating exchange rates, and also stress that China will eventually recognize that imports are a benefit and exports are a cost. Eventually, China will likely become a net importer and that will not be dangerous with a floating exchange rate. And 
this reform will help Chinese policies focus emphasis on stimulating domestic effective demand and achieving sustainable development.

\section{Fixed Exchange Rate Systems}

The idea that a regime of fixed exchange rates is superior to one of flexible rates is deeply ingrained in some (but not all) traditions of economic thought. Many economists have never abandoned the idea that fixed exchange rates are superior to flexible rates. They support their viewpoint by pointing out that the current regime of flexible rates, together with the free movement of capital, is far more unstable and prone to crises than was the previous Bretton Woods regime. A return to fixed exchange rates is therefore seen as the way to ensure more stability in the international economic system. We do not question that in some respects the current regime of floating exchange rates is more unstable than the previous one (based on Bretton Woods), but we argue that trying to go back to a regime of fixed exchange rates is neither feasible nor desirable. The global economic conditions that made Bretton Woods a more-or-less successful exchange rate regime are no longer in place and cannot be resuscitated.

Further, most of the financial instability would have occurred anyway, and is more attributable to globalization of finance, financial leveraging, and financial layering-which was increasingly taking place even before Bretton Woods broke down.

A fixed exchange rate regime can work efficiently to eliminate trade imbalances only in the presence of perfect, or quasi-perfect, capital immobility. Currently, however, the world economy is characterized by very high capital mobility, as most of the Bretton Woods constraints and controls have been removed in a large number of countries-especially the biggest capitalist economies. In addition, there is no effective mechanism that removes trade imbalances - so long as compensating capital flows attenuate exchange rate pressures. Going back to fixed rates would require, therefore, a thorough reform of the international economic system, which should either reintroduce the old controls or invent new ways to limit capital mobility.

We are skeptical that there is any political will to sufficiently constrain capital mobility, nor to reign in international finance to the degree necessary to allow a fixed exchange rate system to operate. It must be noted that the Bretton Woods system was formulated in the context of rigid capital controls. And the major official international financial institutions (World Bank 
and IMF) were envisioned as playing a role in helping to deal with international financial flows that result from trade in goods and services plus official flows among central banks. There was no major role to be played by private capital flows across nations. But as capital restrictions were relaxed and as international capital flows came to consist largely of private flows, the IMF and World Bank were continually called upon to relieve stress.

Moving to a flexible exchange rate system was supported by some economists, most notably by Milton Friedman. The claim was that a flexible system would operate much like the fabled "specie-flow" mechanism, purported to have quickly rectified trade imbalances during the gold standard. The orthodox claim was that, in a flexible exchange rates regime, trade imbalances would cause currencies to adjust, automatically returning trade to equilibrium (somewhat along the lines of Hume's specie flow mechanism). After the three and a half decades of experience since the abandonment of Bretton Woods, this claim is discredited. To be sure, nations have not adopted freely floating exchange rates, but interventions are not sufficiently large to explain the persistence of trade imbalances. In addition to long-term trade imbalances, the world has experienced a great deal of exchange rate instability (especially among developing nations) that is far larger than would be expected simply because of trade imbalances. Thus, the move to flexible exchange rates has not resulted in balanced trade and appears to have contributed to greater global instability. Nations like the US run large, and rising, current account deficits for years and other nations like Japan run large current account surpluses for decades without setting off equilibrium-seeking exchange rate adjustments. And, of course, it is largely private capital flows that offset these current account deficits-with matters made more difficult by "freeing up" international capital markets.

In our view, an essential difficulty with most discussions of exchange rates and the international monetary system is that they concentrate excessively on trade imbalances and the current account while capital movements receive too little attention. As a consequence, money tends to be seen as a medium of exchange. However, in the context of the international economy, in which there are many different currencies, another option is available to those who are deciding how to use money. Money, in the form of a specific currency, can be used to buy commodities, it can be kept idle, or it can be used to buy assets denominated in other currencies. The latter option is profitable when gains derive from purchases in a currency that is expected to appreciate against the domestic currency. In the modern context, much of the international 
reserves are accumulated by governments that want to protect their exchange rates. This lends an asymmetric bias to global demand-some exporters want to keep domestic wages and prices low through austerity to maintain trade advantages, while importers do the same in order to reduce their trade imbalance. It can lead to a "beggar thy neighbor" strategy in which all nations lose.

In the real world, currencies are not used solely for current account transactions, but rather are also used in capital account transactions. Therefore, unless capital is completely immobile, there is no reason for exchange rate adjustments to eliminate current account imbalances. Indeed, with the growth of global finance that easily evades national restrictions, the vast majority of international transactions - certainly more than $90 \%$ of total volume, and probably more than $99 \%$ of total volume - is not directly related to current accounts. If capital controls are neither politically nor technically feasible, then designing an exchange rate system based on the belief that the international monetary system should operate as if goods trade against goods is unlikely to function well.

Before moving on, we note that the European Union created something like an "international currency" for use within the European Monetary Union. The EMU is now in serious crisis, and many commentators have linked the crisis to the adoption of fixed exchange rates within the EMU (by definition, the exchange rate is fixed as there is no difference between a euro issued in Greece versus one issued in Germany). The problem is that the euro exchange rate against other currencies is too strong for periphery nations (Greece, Italy) but actually weak for Germany. But given that all adopted the euro, no exchange rate adjustment is possible to allow Greece or Italy to regain competitive advantage. Further, the strongest net exporter (Germany) is not sanctioned - it doesn't lose its accumulated euro reserves — while net importers are; this leads to the asymmetric bias mentioned above that can depress EMU-wide aggregate demand. However, there is a strong redistribution mechanism - the Target 2 facilitywhich sends euro reserves to nations that lose them through current account balances. That helps to reduce the negative effects of the bias to some degree. We will not go into all of this in detail.

For our purposes, the more important lesson from the EMU experiment was the problem created by divorcing national fiscal policy from currency sovereignty. Each member nation gave up currency sovereignty (abandoned its own currency - the lira, the franc, the mark) but was 
still individually responsible for fiscal policy. That was the critical mistake from the point of view of the sovereign currency approach. So let us turn to that topic in the next sections.

\section{AN ALTERNATIVE APPROACH: SOVEREIGN CURRENCIES}

Most developed countries now have what are often called "fiat" money systems - the dollar system in the US, the yen system in Japan, and so on. While the euro is a fiat money in the sense that it is not "convertible by law into anything other than itself," the individual members of the EMU are users, not issuers, of the euro. Hence, the euro nations are more like US states, or Canadian provinces, than national sovereign governments. China on the other hand has its own currency with a fixed but periodically adjusted exchange rate. It has a fiat currency, and what we call a "sovereign currency." We prefer the second term because it links the currency to its issuer, and to the power of the issuer-what we can call sovereign power.

In this section we very quickly summarize the main components of the sovereign currency approach to money and to monetary and fiscal policy. This is deliberately presented in a non-technical manner. Note also that the discussion will tend to use the US and the dollar as examples, but the general principles laid out apply to any sovereign government and its currency. Below we will address the situation in China, based on our understanding of Chinese monetary and fiscal operations already discussed above. We use this order of exposition because the US procedures are better-known to economists and can be considered to be the "general case" as similar procedures are used in the developed countries that have sovereign currencies. China's specific operations are a bit different, and, as discussed, China currently operates with a closely managed exchange rate. In that sense it is somewhat closer to a pegged currency than to a floating, fiat currency. Further, the US operations provide some lessons to be used to formulate reform recommendations for China as it moves toward greater flexibility of its exchange rate.

\section{Background}

In sovereign nations, the government chooses the state money of account (dollar, RMB, yen) and issues high powered money (HPM or coins, paper money - central bank or treasury notes, and bank reserves) is the state-issued currency. We can also include treasury debt (bills or bonds; or in China's case we can include PBC bills) because they are substitutes for HPM that 
pay interest (indeed, treasuries are really reserve deposits at the central bank that pay higher interest than regular reserves), so we will include HPM plus treasuries as the government currency monopoly. One must deliver these in payment of central government taxes, which destroys currency (electronic bank reserves are literally wiped clean when taxes are paid). If government emits more in its payments than it redeems in taxes, currency (broadly defined as HPM plus treasuries) is accumulated by the nongovernment sector as financial wealth.

\section{Leveraging Government High Powered Money}

Nations usually provide some institutions-for example, chartered banks--with a special relationship to the sovereign government, allowing them to act as intermediaries between the government and the nongovernment sectors. Most importantly, modern government makes and receives payments through banks. Hence, when a household (or firm) receives a payment it takes the form of a credit to a bank account; one pays taxes through a debit to that account. Banks, in turn, clear accounts with the government and with each other using reserve accounts (high powered money, or currency broadly defined) at the central bank, which can ensure clearing at par (the Fed was created in the US in 1913 with one of its main missions to ensure par clearing among banks). To strengthen that promise, many governments have introduced deposit insurance so that for most purposes, bank money functions like government money. We can think of that as leveraging sovereign money-since ultimately it is backed by currency used to clear accounts.

Government normally stands behind this "leveraging". Lender-of-last-resort facilities at the central bank ensure liquidity of "private money". Deposit insurance provided by the treasury ensures that certain classes of bank creditors (insured depositors) do not lose if a bank's assets (loans, bonds, and increasingly securities such as mortgage-backed securities) go bust. This reduces the market discipline imposed on banks, so discipline must be imposed by government regulators and supervisors.

\section{Credit and the Relation to Sovereign Currency}

When a bank makes a loan, it accepts an IOU and issues its own IOU; the bank's debtor clears his IOU by delivering the bank's IOU, which it must accept. All modern banking systems include a clearing house so that a bank's debtor can deliver the liability of any bank-and banks use currency (central bank reserves) to clear among each other. Indeed, even tax liabilities are 
met by delivering bank liabilities, with the central bank clearing accounts between private banks and the treasury. There is a hierarchy of monies, with bank liabilities used by the nongovernment sector and with government liabilities used for net clearing among banks and with the government (Bell 2001). When a bank makes a tax payment for its customer, the central bank debits the bank's reserves. When the treasury makes a payment using its account at the central bank, the recipient's bank is credit with reserves. So, effectively, banks "intermediate" between the state and households or firms. This is why coins and paper notes are not usually used in payments to and from government. Indeed, coins and paper notes enter the economy largely through withdrawals from banks.

\section{Central Bank Reserves and Interest Rate Targeting}

Given this arrangement, banks must hold reserves for clearing (as in the US), or have ready access to them (as in countries like Canada, where the central bank offers overdraft facilities and banks attempt to hold zero net reserve balances). Ultimately, a central bank cannot refuse to provide reserves for clearing if it wishes to maintain an orderly payments system with par clearing. Further, as Moore (1988) insists, to hit its interest rate target the central bank must accommodate the demand for reserves.

Monetary policy should therefore be seen as targeting an overnight interest rate target, not one of determining reserves and the "money supply". To hit its rate target, it must accommodate reserve demand in a nondiscretionary manner. This also leads to a revised view of the function of treasuries, classifying bond sales and purchases as part of monetary policy rather than associating them with fiscal policy. This is true regardless of the authority involvedwhether it is the treasury or the central bank-since functionally the impact is the same. That is, an open market sale or a new treasury issue both lead to a substitution of government bonds for bank reserves; an open market purchase or redemption of a maturing treasury bond both add reserves to the system. Bonds should be thought of as a higher interest-earning alternative to bank reserves.

\section{Treasuries and Sovereign "Borrowing"}

That also leads to an entirely different approach to the topic of "sovereign borrowing". Sale of a US Treasury bond by the central government bears no resemblance to a corporate bond sale. The reason is that the sale of a government bond is accomplished by debiting reserves - in other 
words one kind of government IOU (bond) replaces another government IOU (reserves). When a corporation sells a bond it is issuing a new IOU to obtain a claim on another (usually a bank deposit). In fact, then, only if a corporation were replacing, say, its short term IOU (maybe its own commercial paper) with a long term IOU (a bond) would the operation be similar to that of the Treasury's bond sale. One can think of Treasury bond sales or Fed "quantitative easing" bond purchases as nothing but "duration trades" in the government's own IOUs.

\section{Can the Sovereign Government "Run Out" of Its Own Currency?}

A sovereign government cannot run out of its own currency. If there are banks that want to sell assets to the central bank, it can buy them by crediting bank accounts with reserves. If there are unemployed workers who want to work for a wage, government can hire them by crediting bank accounts. There may be reasons why hiring unemployed labor, or buying output from private firms, is not desired in a slump, but "affordability" is not a legitimate excuse when offered by a sovereign government that issues its own nonconvertible monopoly currency. And it cannot be a matter of insufficient demand for the currency - unemployment and unsold goods are together strong evidence of an unmet demand for the currency - a demand that can be easily met by the monopoly supplier of currency.

Understanding how a sovereign currency works would advance public policy formation a great deal. Affordability is never the issue; rather, the real debate should be over the proper role of government: how it should use the monetary system to achieve the public purpose.

\section{Monetary and Fiscal Operations in a Sovereign Nation.}

In this final section we look in some detail at actual monetary and fiscal operations in the US; similar procedures are followed in other developed nations that issue their own currency such as Canada, Australia, and Brazil (all of which have been studied in detail by those using the Modern Money Theory framework). We examine these procedures and then turn to China's operating procedures.

Above we have analyzed fiscal and monetary policy operations in general while leaving out some specific procedures adopted. In practice, countries adopt specific rules or laws that dictate the procedures to be followed. For example there are two very commonly adopted restrictions: the central bank cannot directly accept treasury IOUs (such as bills or bonds), and the treasury must spend out of its accounts at the central bank. The implications of these rules 
are that the treasury must obtain deposits in its account at the central bank, but the central bank cannot allow an "overdraft" nor can it buy treasury debt. For that reason the treasury needs to receive tax payments into special "tax and loan accounts" it holds in private banks then transfer those funds to the central bank before spending. Further, if sufficient tax revenue is not flowing into these special bank accounts, the Treasury must sell bills or bonds to private banks (these sales in the US are to special "dealer" banks) to obtain deposits in the special accounts that can then be transferred to the central bank to spend.

This would appear to constrain treasury spending to the funds it obtains from taxes or from bond sales. That in turn raises questions like "what happens if markets refuse to buy the bonds?" Could bond markets prevent the treasury from borrowing and hence from deficit spending? As we will argue, that actually cannot happen. The special operating procedures adopted ensure that these rules do not really constrain fiscal policy. Let us see why.

We'll use the case of the US, which has adopted "constraints" that are typical among the high income, developed, market economies in the West. Here is the actual spending process in place today. The US Treasury holds accounts in both private banks and the Fed, but can write checks only on its account at the Fed. Further, the Fed is prohibited from buying Treasuries directly from the Treasury (and is not supposed to allow overdrafts on the Treasury's account) and thus the Treasury must have a positive balance in its account at the Fed before it spends. Therefore, prior to spending, the Treasury must replenish its own account at the Fed either via balances collected from tax (and other) revenues or debt issuance to "the open market". As a result, in the US case there are usually six transactions related to deficit spending operations. $^{26}$

1. The Fed undertakes repurchase agreement operations with primary dealers (in which the Fed purchases Treasury securities from primary dealers with a promise to buy them back on a specific date) to ensure sufficient reserve balances are circulating for settlement of the Treasury's auction (which will debit reserve balances in bank accounts as the Treasury's account is credited) while also achieving the Fed's target rate. It is well-known that settlement of Treasury auctions are "high payment flow days" that necessitate a larger quantity of reserve

\footnotetext{
${ }^{26}$ See Modern Money Theory: A Response To Critics", by Scott Fullwiler, Stephanie Kelton and L. Randall Wray, January 2012, PERI Working Paper Series, Number 279, http://www.peri.umass.edu/fileadmin/pdf/working_papers/working_papers_251-300/WP279.pdf
} 
balances circulating than other days, and the Fed accommodates the demand. (Note that the point here is not that the Fed necessarily engages in operations that are equal to or greater than the auction, but that the operations ensure that sufficient balances circulate such that the auction settles without the effective federal funds rate for the day moving above the target rate. This requires that the balances already in circulation plus those added via operations are sufficient to settle the auction and enable banks in the aggregate to end the day with their desired positions at the target rate largely equal to actual positions.)

2. The Treasury's auction settles as Treasury securities are exchanged for reserve balances, so bank reserve accounts are debited to credit the Treasury's account, and dealer accounts at banks are debited. Treasury auctions can only settle via reserve balances using the Fed's Fedwire clearing and settlement system. The auction itself is an asset swap of reserve balances and thus does not affect the private sector's net wealth.

3. The Treasury adds balances credited to its account from the auction settlement to tax and loan accounts. This credits the reserve accounts of the banks holding the credited tax and loan accounts.

4. (Transactions 4 and 5 are interchangeable; that is, in practice, transaction 5 might occur before transaction 4.) The Fed's repurchase agreement is reversed, as the second leg of the repurchase agreement occurs in which a primary dealer purchases Treasury securities back from the Fed. Transactions in 1 above are reversed.

5. Prior to spending, the Treasury calls in balances from its tax and loan accounts at banks. This reverses the transactions in 3 .

6. The Treasury deficit spends by debiting its account at the Fed, resulting in a credit to bank reserve accounts at the Fed and the bank accounts of spending recipients. This increases the net financial wealth of the private sector.

(The analysis is much the same in the case of a deficit created by a tax cut instead of an increase in spending. That is, with a tax cut the Treasury's spending is greater than revenues just as it is with pro-active deficit spending.)

What we want to stress is that the end result is exactly the same as if a "consolidated government" spent by directly crediting bank reserves (while the bank credits deposit accounts of recipients of government spending) and then sells government bonds to offer an (higher) interest-earning alternative to excess bank reserves. However, with the procedures adopted due 
to the self-imposed constraints the transactions are now more complex and the sequencing is different. In any case, the nongovernment sector ends up with net financial assets (government bonds) when government deficit spends.

Note that only reserve balances can settle US Treasury auctions of bonds via Fedwire (the clearing mechanism) and the only sources of reserve balances over time (that is, aside from various short-term effects from autonomous changes to the Fed's balance sheet) are loans from the Fed or the Fed's purchases of financial assets either outright or in repurchase agreements. The Fed normally purchases Treasury securities or requires Treasury securities as collateral for repurchase agreements (in the aftermath of the global crisis, the Fed has engaged in highly unusual purchases of a wider variety of assets, and has lent against various kinds of assets).

Since existing Treasury securities were issued as a result of a previous government budget deficit, it is the case that the reserve balances required to purchase Treasury securities are the result of a previous government deficit or a loan (including repurchase agreements or purchases of private sector securities) from the Fed to the non-government sector. This is true even though the Treasury must have a positive balance in its account before it can spend, and even though the Fed is legally prohibited from providing the Treasury with overdrafts in its account due to the "self-imposed constraint."

In other words it is "as if" the Fed "finances" Treasury deficits by directly purchasing the bonds. (This is often referred to as "central bank money-financed budget deficits", and is thought to be prevented due to the constraints imposed that prohibit the Fed from buying bonds directly from the Treasury.) The question is whether all of this complexity really matters. If we had a simplified, consolidated government, a budget deficit would lead the nongovernment sector to net accumulate claims on the government. Initially these would be in the form of currency, but if government offers bonds as an interest-earning alternative, then given portfolio preferences at least some (and probably most) of the currency would be exchanged for bonds.

If we separate the treasury and central bank and impose operational rules like those in the US, then deficit spending will lead to the same results. While bonds might be sold first, and deposits transferred from private banks to the Fed before the Treasury spends, at the end of the spending process banks have issued more deposits and hold some combination of more bonds and more reserves. Just as in the consolidated example above, bank deposits outstanding at the end of the process equal bank holdings of currency (reserves) plus government bonds; nonbanks 
hold a combination of currency, demand deposits, and bonds; and the quantity of demand deposits held by households and firms equals bank holdings of government bonds and currency (reserves)—which equals the government's deficit spending.

Further, note that the Treasury's tax and loan account operations are for the purpose of aiding the Fed's ability to achieve the target rate, as is well established in the Fed's own literature and annual reports. And while the Treasury must issue bonds in order to replenish its own account when it runs a deficit, the interest rate on these bonds is largely determined by arbitrage against the Fed's target (overnight) rate. This suggests that the self-imposed constraint is not really a constraint at all. In the absence of this constraint, the government would have the choice of spending with no bond sales while paying the target rate on reserve balances or issuing debt at essentially the central bank's target rate. For the US, the former is analogous to a scenario with no self-imposed constraint and with the Treasury obtaining overdrafts to its account at the Fed when it deficit spends, whereas the latter is obviously what occurs now with no overdrafts allowed. In other words, prohibiting overdrafts leaves the Treasury issuing bonds that arbitrage against the Fed's target rate.

There is no economically significant difference - if given the choice between an overdraft at the target rate and issuing debt at roughly the target rate; it is not economically significant for the Treasury's purposes if the former choice is prohibited. (And while the Treasury may issue longer-term bonds that can be issued at significantly higher interest rates than the Fed's target rate, for both the general and US cases this is a choice, not anything enforced by private debt markets.) Even under current operations, interest rates are a matter of political economy_influenced by policy_rather than being set in a loanable funds market or subject to the whims of bond markets.

On current requirements, if the Treasury does not have sufficient deposits in the private banks (tax and loan accounts) to transfer to cover mandated spending, it must first sell bonds. The question is this: will the banks buy them? The answer is pretty simple. We know that even if the banking system has no excess reserves, the Fed will respond to any pressure on reserves that might be created by banks trying to buy the bonds. With an interest rate target, the Fed always accommodates. That is the macro level answer.

At the micro level, special banks — dealers_-stand ready to buy bonds. To maintain their relationship with the Treasury, they will not refuse. (In the US there are 21 primary dealers 
obligated to bid at US government debt auctions - there is literally no chance that the US Treasury could fail to sell bonds.) The dealers would then try to place the bonds into markets. For a sovereign currency issuer that will make interest payments as they come due, there is no fear of involuntary default. It is conceivable that the Treasury has offered maturities that do not match the market's desires. In that case, prices need to adjust to place the Treasuries - or the dealers will get stuck with the bonds.

In any case, this mismatch is easily resolved if the Treasury offers only very short maturities. This might not seem obvious unless one realizes that short maturity Treasuries are simply bank reserves that pay a slightly higher interest. As the Fed (like most central banks) targets the overnight rate, reserves can be obtained at that rate. Assuming the central bank is not running an "operation twist" policy (buying longer maturities to target longer term interest rates), it lets the "market" determine rates on longer maturities. The Treasury can always issue short term bonds at a market-determined mark-up above the overnight target - the choice among issuing bills, short term bonds, or long term bonds is the Treasury's (called “debt management").

The question, then, is not really "will the banks buy Treasuries", but "at what price". Very short-term Treasury debt is a nearly perfect substitute for reserves on which the Fed (now) pays interest. Hence, a slight advantage given to Treasury debt will ensure that (non-dealer) banks will exchange reserves for Treasuries. If the Treasury is obstinate, insisting on selling only long maturities, then portfolio preferences can increase rates-perhaps beyond what the Treasury wants to pay. The solution, of course, is to offer maturities the market prefers - or to pay rates necessary to induce the market to take what the Treasury prefers to issue. Clearly this is a very easy "coordination problem" to resolve.

Current operating procedure requires that the Treasury move deposits from private banks to the Fed. At the same time, the private bank reserves are debited. The Fed does not and will not prevent this from occurring. If the transfer should leave banks short of reserves, the Fed accommodates - either through a temporary bond purchase or by lending at the discount window. In practice the Treasury coordinates with the Fed so that the Fed is ready to provide reserves as needed. Again, operating with an overnight target rate requires accommodation of the demand for reserves - it is not a choice if the central bank wants to hit its target. 
Finally, note that in the case of budget deficits, the private sector's net financial wealth has been increased by the amount of the deficit. That is, the different sequencing of the Treasury's debt operations does not change the fact that deficits add net financial assets rather than "crowding out" private sector financial resources. Indeed, primary dealers finance their purchases of bonds at auction in the repo market, mostly using Treasuries as collateral, while the newly issued bonds will likely serve as collateral for further credit creation in financial markets. Far from "crowding out," bonds can actually enable more private credit creation than would occur in their absence.

In summary, separating the Treasury and the Fed and adding the rule that the Treasury must finance its operations in the open market results in the six transactions described above for the Treasury's debt operations compared to the relatively simpler operations that would be required to let deficit spending proceed in the absence of these rules. Nevertheless, the nature of these operations as described by the general case of a consolidated government/central bank balance sheet all remain completely intact. Unfortunately, the added complexity is counterproductive because it leads to poor understanding among economists, poor modeling, and bad policy choices. If economists and policy makers understood that the sovereign currency general case explains the true nature of government debt operations, we suggest policy could be markedly improved.

\section{Budget Deficits and Sectoral Balances.}

There is one final topic to be discussed before we apply this approach to China. In the previous sections we have argued that all else equal budget deficits increase net financial assets held by the nongovernment sector. In this final section we discuss the interrelations among sectoral balances more generally, following the work of Wynne Godley. ${ }^{27}$

If we sum the deficits run by one or more sectors, this must equal the surpluses run by the other sector(s). We can state this principle in the form of a simple identity:

\section{Domestic Private Balance + Domestic Government Balance + Foreign Balance $=0$}

\footnotetext{
${ }^{27}$ See L. Randall Wray, "Godley Got It Right", in Contributions to Stock-Flow Modeling: Essays in Honor of Wynne Godley, edited by Dimitri Papadimitriou and Gennaro Zezza, Palgrave Macmillan 2012.
} 
For example, let us assume that the foreign sector runs a balanced budget (in the identity above, the foreign balance equals zero). Let us further assume that the domestic private sector's income is $\$ 100$ billion while its spending is equal to $\$ 90$ billion, for a budget surplus of $\$ 10$ billion over the year. Then, by identity, the domestic government sector's budget deficit for the year is equal to $\$ 10$ billion. Saving flows accumulate to stocks, so we know that the domestic private sector will accumulate $\$ 10$ billion of net financial wealth during the year, consisting of $\$ 10$ billion of domestic government sector liabilities.

As another example, assume that the foreign sector spends less than its income, with a budget surplus of $\$ 20$ billion. At the same time, the domestic government sector also spends less than its income, running a budget surplus of $\$ 10$ billion. From our accounting identity, we know that over the same period the domestic private sector must have run a budget deficit equal to $\$ 30$ billion ( $\$ 20$ billion plus $\$ 10$ billion). At the same time, its net financial wealth will have fallen by $\$ 30$ billion as it sold assets and issued debt. Meanwhile, the domestic government sector will have increased its net financial wealth by $\$ 10$ billion (reducing its outstanding debt or increasing its claims on the other sectors), and the foreign sector will have increased its net financial position by $\$ 20$ billion (also reducing its outstanding debt or increasing its claims on the other sectors).

It is apparent that if one sector is going to run a budget surplus, at least one other sector must run a budget deficit. In terms of stock variables, in order for one sector to accumulate net financial wealth, at least one other sector must increase its indebtedness by the same amount. It is impossible for all sectors to accumulate net financial wealth by running budget surpluses. We can conclude that if one of three sectors is to run a surplus, at least one of the others must run a deficit.

Let us summarize the main points that follow on from the identity. First, the three balances must balance to zero. This implies it is impossible to change one of the balances without having a change in at least one other. Second, at the aggregate level, spending (mostly) determines income. A sector can spend more than its income, but that means another spends less. While we can take government spending as more-or-less discretionary, government tax revenue (government's equivalent to its income) depends largely on economic performance. In practice, tax receipt growth is highly variable, moving pro-cyclically (growing rapidly during 
booms and collapsing during slumps) — which makes the ex post budget balance also variable, with deficits increasing in a slump and falling during robust economic growth.

Government can always decide to spend more (although it is politically constrained), and it can always decide to raise tax rates (again, given political constraints), but it cannot decide what its tax revenue will be because we apply a tax rate to variables like income and wealth that are outside government control. And that means the budgetary outcome-whether surplus, balanced, or deficit—is not really discretionary.

Turning to the foreign sector, exports are largely outside control of a nation (they are "exogenous" or "autonomous" to domestic income). They depend on lots of factors, including growth in the rest of the world, exchange rates, trade policy, and relative prices and wages (efforts to increase exports will likely lead to responses abroad, so it is not necessarily effective to push down domestic wages). It is true that domestic economic outcomes can influence exports - but impacts of policy on exports are loose.

On the other hand, imports depend largely on domestic income (plus exchange rates, relative wages and prices, and trade policy; again, if domestic policy tries to reduce imports this would almost certainly lead to responses by trading partners that are pursuing trade-led growth). Imports are largely pro-cyclical, too. Again, the current account outcome-whether deficit, surplus, or balanced — is also largely nondiscretionary. What is discretionary? Domestic spending - by households, firms, and government - is largely discretionary. And spending largely determines our income. Sectoral balances, however, should be taken as mostly nondiscretionary because they depend in very complex ways on the discretionary variables plus the nondiscretionary variables and on the constraints imposed by the macro identity.

For that reason, it makes most sense to promote spending that will utilize domestic resources close to capacity, and then let sectoral balances fall where they may. As we will argue later, the best domestic policy is to pursue full employment and price stability — not to target arbitrary government deficit or debt limits, which are mostly nondiscretionary, anyway.

\section{IMPLICATIONS FOR CHINA}

We now apply what we know about the way sovereign currency works to the case of China. We will use this understanding to address the following topics: sectoral balances; policy options (fiscal, monetary, and exchange rate); and policy to counter a financial crisis should it occur. 


\section{Sectoral Balances and Government Budgets}

Let us begin with China's three sector balances. The following graph shows the domestic private, the government, and the foreign balances:

Figure 10: 1990-2012 China Main Sector Balance

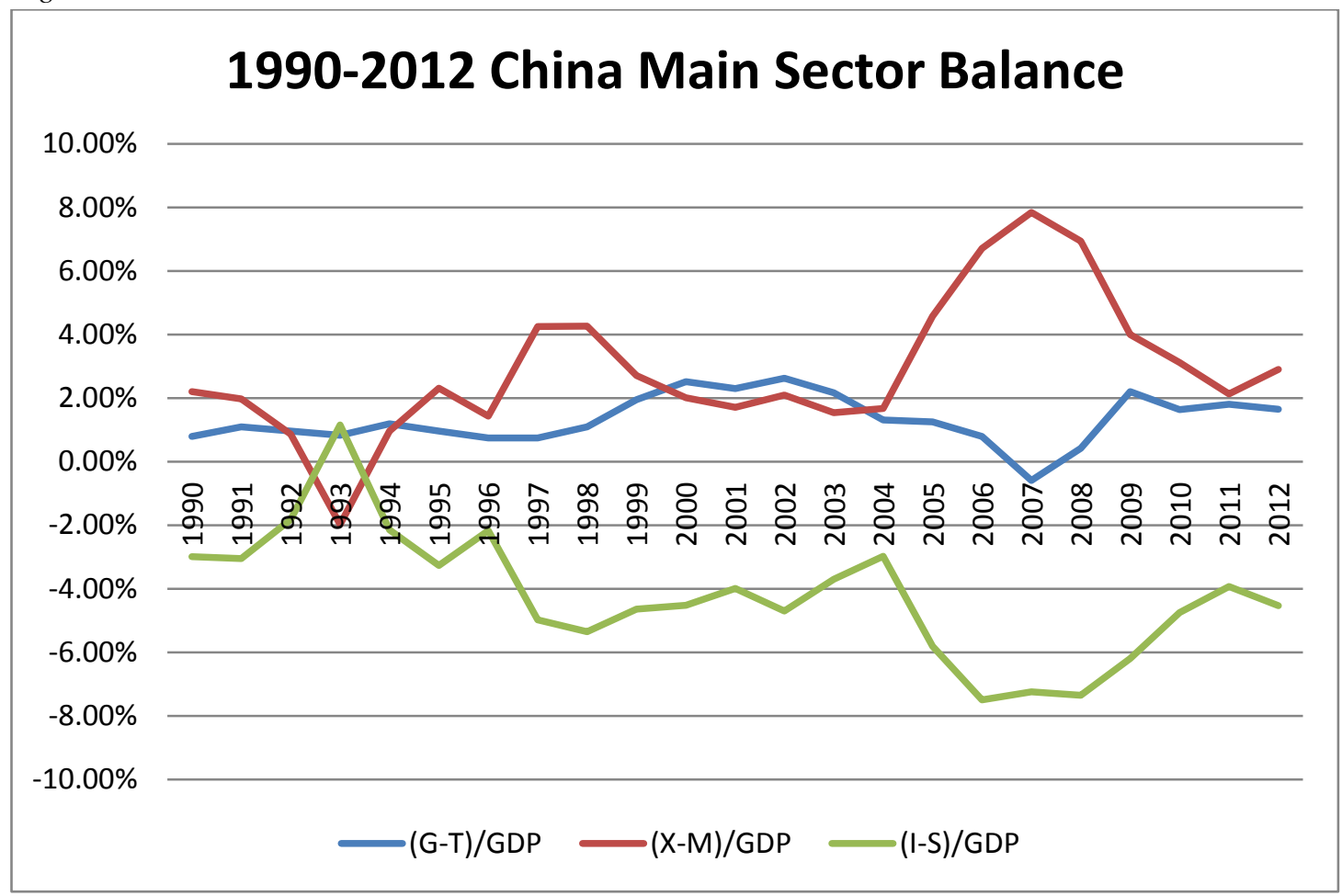

Source: China statistics year book, China Custom statistics, National Bureau of Statistics of China

Recall from above that these must "balance" by identity—-the sums across the deficits and surpluses of the sector must always equal zero. Note that we have used the available statistics to compute the balances: government spending less tax revenues, exports less imports, and investment minus saving; to scale these we express as a percent of GDP. In some respects these statistics are less than ideal. In the national accounts saving is computed as a residual (and there is often a large statistical discrepancy between the aggregate measures of income and spending), and, indeed, we have calculated the private sector balance as a residual (government balance less foreign balance). Further, what we really want is the financial flow of each sector (for example, the current account rather than net exports) to more accurately estimate the financial balances. However, these national statistics are sufficient for our purposes. 
We see that the government budget deficit (nearly 2\% of GDP in 2011) plus the export balance (also about 2\% in 2012) equals the private sector balance of about 4\% in 2011 (saving exceeds investment by about $4 \%$ of GDP, so investment minus saving is a negative $4 \%$ ). In normal Keynesian terminology, we can say that the "injections" of budget deficits plus an export surplus equals the "leakage" of saving in excess of investment.

Since the start of the Global Financial Crisis, the net export balance has declined considerably (although it bounced back up in 2012). All else equal, this would have led to a large decline of the domestic private sector's positive balance. However, the budget deficit rose early in the crisis, stabilized, and then increased again in 2012, partly offsetting the decline of net exports so that the adjustment to the private sector's surplus was smaller than it would have been. Note that if China's net exports trend lower, then the only way to maintain a constant private sector surplus is to have the government sector's deficit grow.

The following chart shows the central government's deficit over recent years. It is evident that trends of the central government's deficit drive the overall government sector balance shown in the figure above. Since the GFC, the trend has been for the central government budget deficit as a ratio to GDP to rise. Still, it is quite low in comparison to most developed countries in the West. The picture is quite different, however, if we exclude central government support of local government spending. The next chart excludes transfers and tax rebates made to local government; hence it shows central government revenue less direct spending. In other words, central government spending on its own programs is small relative to its revenues - its surplus is growing rapidly since 2000. This is because its own revenue has been growing quickly while its spending has not. Above we discussed the fact that China's spending on social programs lags far behind what is typical for middle income nations. Further, while the flow of tax revenue has increasingly shifted from local government and to the national government, responsibility for social programs has actually been shifted to local government. And, as we discussed earlier, residents of poorer counties in China receive much less in the way of public spending. We'll return to that topic shortly. 
Figure 11: China's Central Government Deficit, Percent of GDP (This includes central government transfers and tax rebates to local governments)

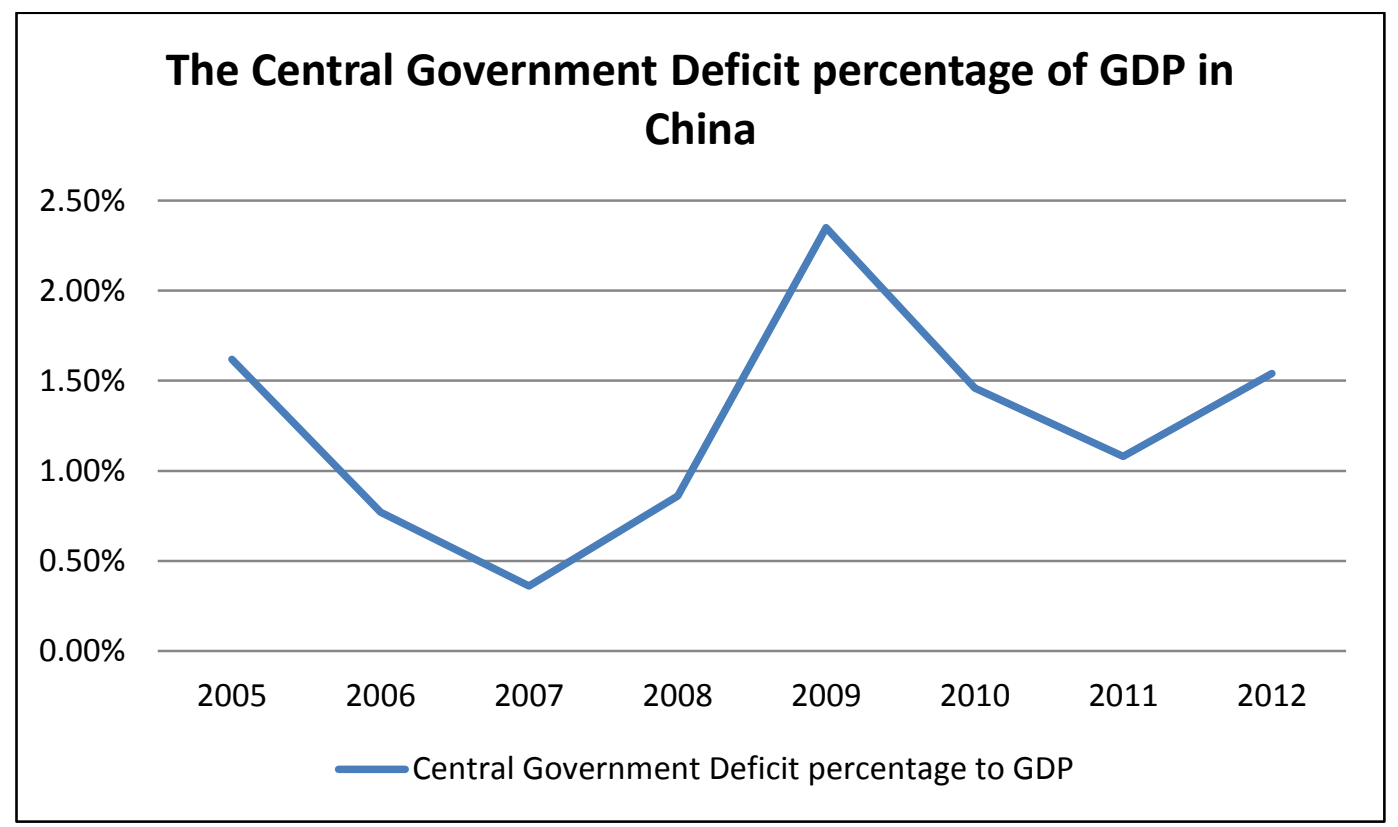

Source: Ministry of Finance of the People's Republic of China website, http://www.mof.gov.cn/

Figure 12: Central Government Fiscal Deficit as Percent of GDP (This excludes central government transfers to local government)

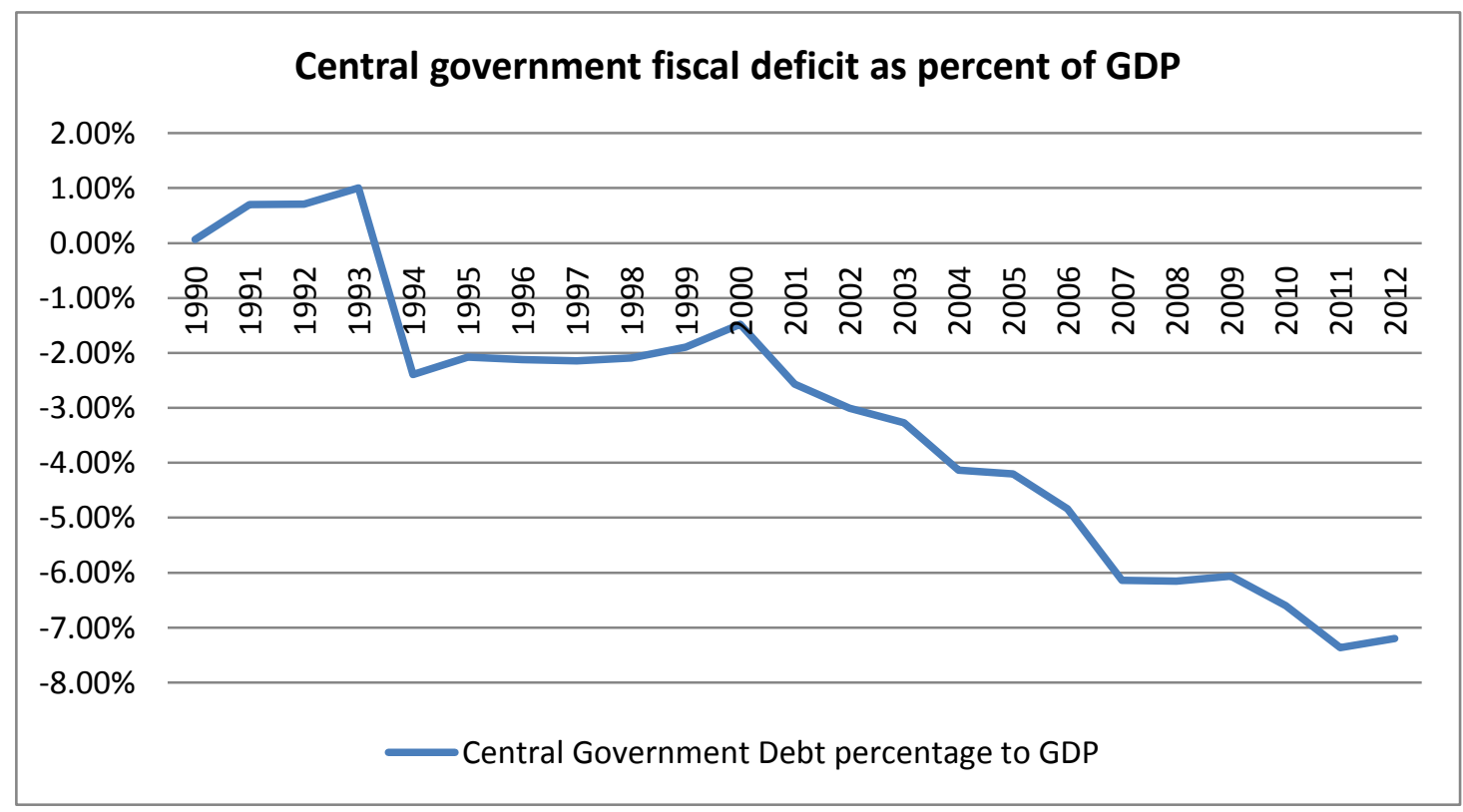

Source: China statistics year books and 2012 data are from the website.

http://www.mof.gov.cn/zhengwuxinxi/caizhengxinwen/201303/t20130319_782332.html 
Central government debt is quite small relative to GDP, as the next chart shows. While it peaked a decade ago at just $20 \%$ of GDP, it has generally declined since to just $15 \%$ in 2011 . Even with slightly larger budget deficits now and possibly into the future, the debt ratio will rise only very slowly so long as GDP keeps growing at a robust pace. It is very difficult to understand why there is a move to reduce central government budget deficits, even based on conventional arguments, given how low the ratio is. Let us turn to local government budgets before pursuing that topic, however.

Figure 13: Central Government Debt as a Percent of GDP

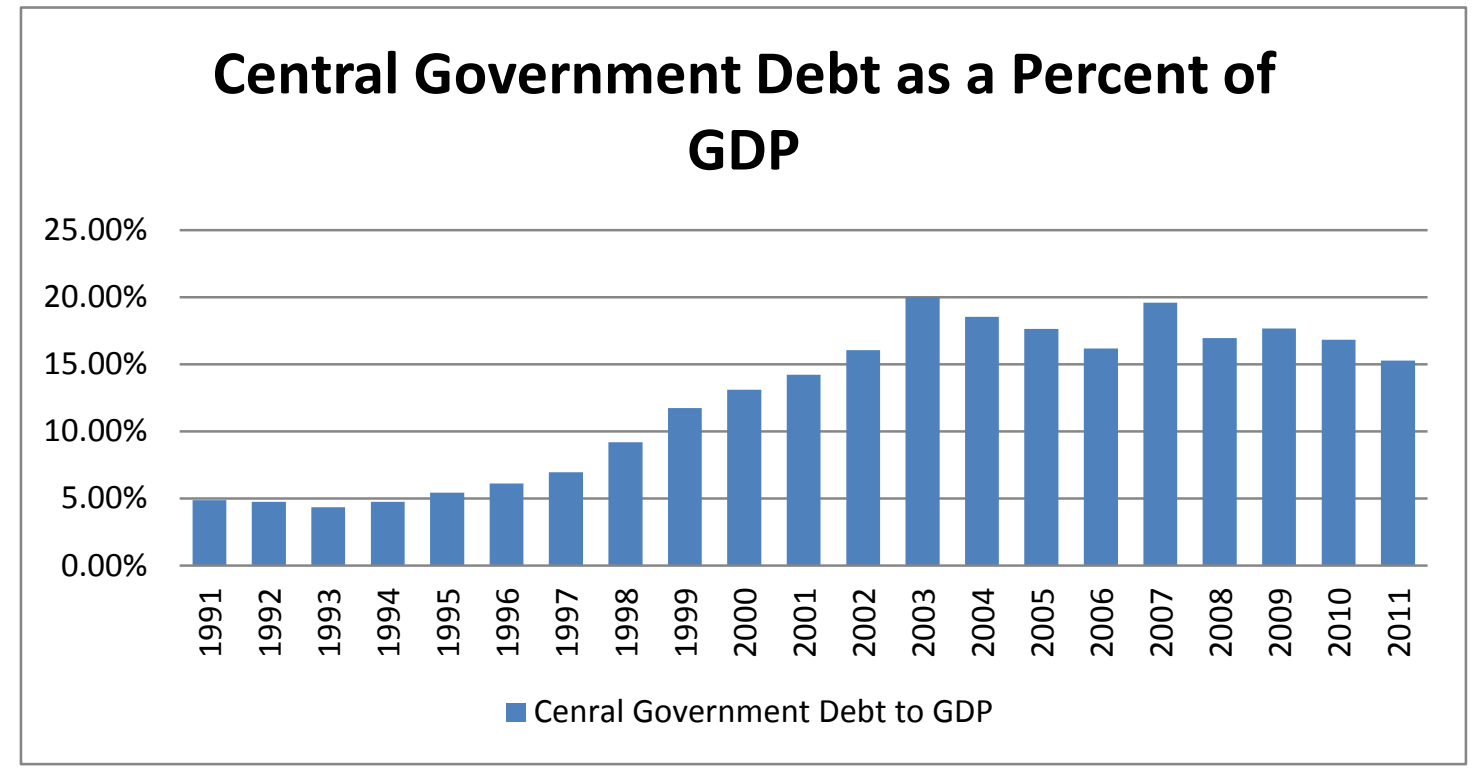

Source: China Center for Economic Research database

Leaving to the side central government support of local governments, we find that the situation is much different at the local level as local revenue falls far short of spending: 
Figure 14: Local Government Budget Deficit \% of GDP; (This excludes transfers from the central government to local government)

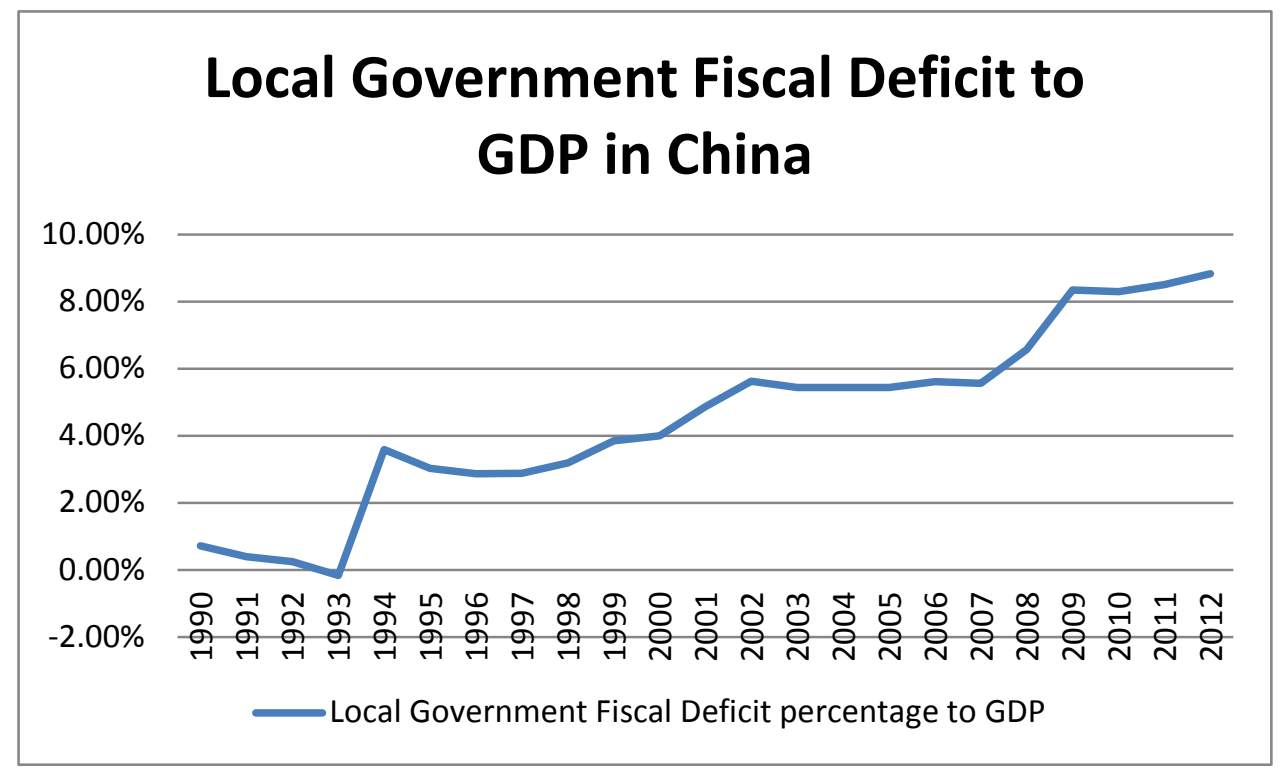

Source: China statistics year books

This is almost a mirror image to the central government's finances, as local governments run growing budget deficits - which are made up by transfers from the central government. ${ }^{28}$ Local government debt is reported to be about $25 \%$ of GDP today, significantly higher than the central government's debt ratio:

${ }^{28}$ There is some skepticism about the data on local government finances. Some estimates put the local government debt ratio at more than $70 \%$ (Feng Beilin, "Study on local government SIVs and local government debt", China State Finance, 2009, vol .18, pp 43-45); However, also see Sun, Jing, "Chinese local government debt, current situation, problems and strategy", Friends of Accounting, 2013, vol 3. pp: 58-60. 
Figure 15: Local Government Debt as a Percent of GDP

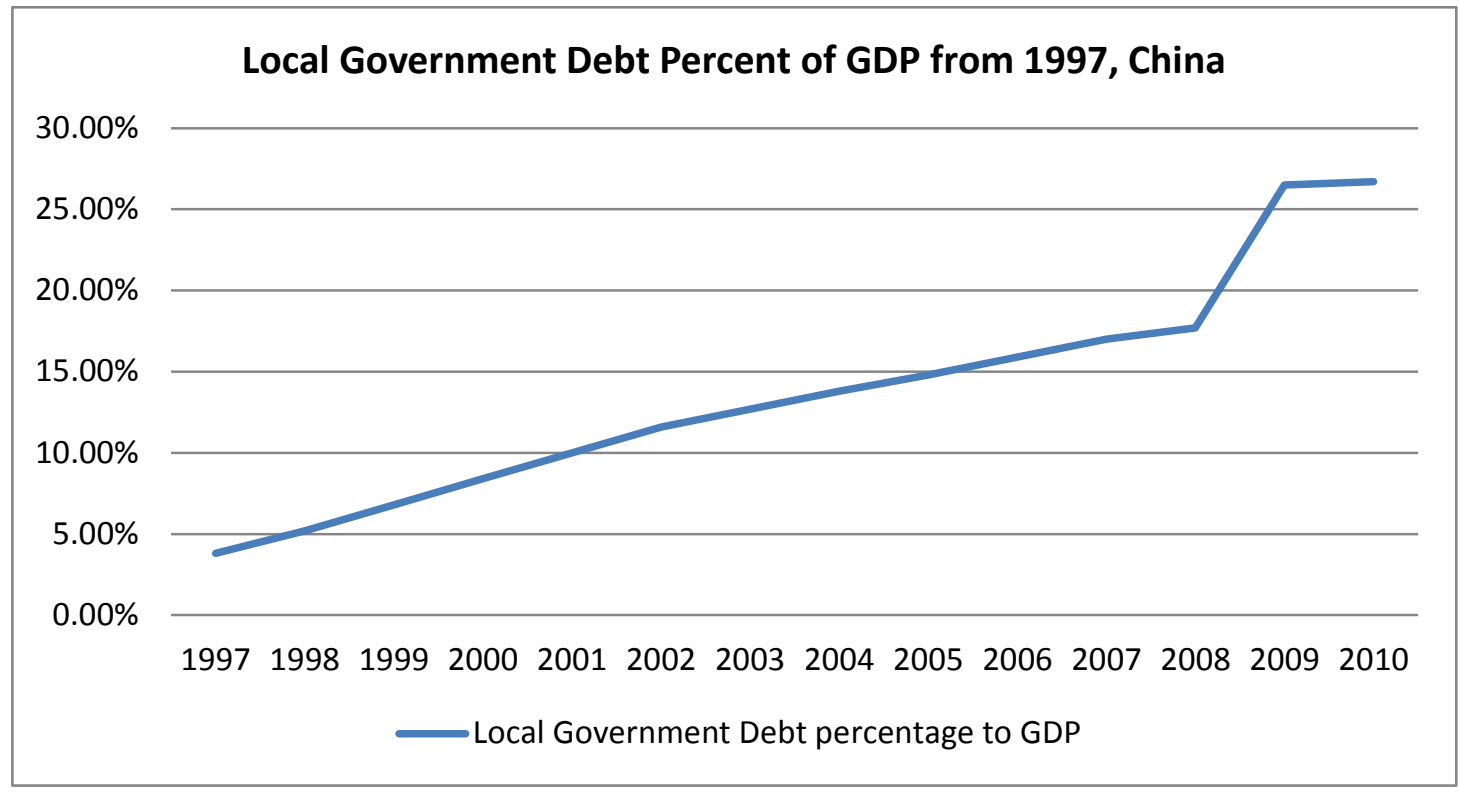

Source: Date Source: Based on the "No.35 audit results announcement, 2011"from the National Audit Office

We note that reported data on local government debt appears too low. Until recently local governments had very restricted ability to issue debt. We suspect that the reported data understates local government liabilities because it appears that liabilities have been moved "off balance sheet" to special investment vehicles (SIVs). At the same time, central government reported debt seems to be too large given the large budget surpluses reported until recently. It is possible that the reported number includes PBC debt-bills - issued as part of monetary policy. These issues need further investigation.

Notwithstanding these questions about the reported data, from the sovereign currency perspective the policy stances of local governments and of the central government appear to be the reverse of prudent policy. In a sovereign nation, it is better to run tight fiscal policy at the local level and looser policy at the national level. The sovereign government faces no solvency risk, as the currency issuer it can make all payments as they come due. By contrast, local governments can and sometimes do default on obligations because they cannot generate enough revenue to service debt.

Further, local government might engage in risky practices to finesse or to hide deficits and debts. Much as financial institutions created SIVs to make their balance sheets look better, a local government might move debts off its balance sheet. Local governments that are revenue- 
constrained might also engage in short-run policies to obtain financing that are not sound for the long-run. For example, selling land to developers to finance local government activities might not be in the long-run interest of the community.

Summing local government and central government deficits gives us the government balance reported in the sectoral balances graph above. The growth of local government deficits was halted only very recently as the central government's deficit rose. As discussed in the introduction, we see this as a welcome development, since the sovereign currency issuer has the fiscal capacity to service debt.

\section{Policy Options}

\section{a) Fiscal Policy}

Above we outlined China's fiscal and monetary policies and detailed US policy operations. There is a great deal of similarity in fiscal operations. In both countries fiscal policy is implemented with the coordination of the treasury, the central bank, and commercial banks. Effectively, the commercial banks act as agents of government to make payments and to receive revenues that are then transferred to the central bank. As the central bank acts to clear accounts among banks and with the government, it is necessarily involved in fiscal operations. Current operating procedures in China appear to be appropriate to allow fiscal operations to function smoothly.

As discussed in the previous section, we think the distribution of the fiscal burden between local government and central government is imbalanced. Central government fiscal policy is too tight, while local governments probably need to tighten. We do not know if the reported data for local governments are accurate. It is possible that debt has been moved off balance sheets, or unreported. There could be contingent liabilities that are not included. But even if the data are accurate, we believe that the difference between central and local government finances (as reported) is still worrying. The burden on local government appears to be too high. Not only are local governments responsible for social spending (that many of them probably cannot afford) but they are also engaged in what could be called competitive development - trying to increase infrastructure to attract capital development and good jobs. With sometimes severely constrained revenue sources, they sell land to developers to raise the funds needed for infrastructure. In some cases, the result is environmental degradation, which as 
the ADB says, imposes a disproportionate share of the costs on the poor who actually consume few of the natural resources and who receive little of the benefits of public spending. (ADB 2013-3, cited above)

A far better strategy would be to move more of the responsibility for social spending and even local public infrastructure spending to the central government. This would allow for more equal shares to be distributed across regions, or even for progressive distribution of central government provisioning (higher per capita spending for poorer communities). As the sovereign currency issuer, the central government does not face an "affordability" constraint. It does need to worry about spending too much — which can be inflationary, might pressure the exchange rate, and would likely generate bottlenecks that deprive firms of resources they need.

But it is much better to put more of the spending at the central level precisely because that is the level at which policymakers should be on-guard against inflation. Local government is much less likely to decide to reduce spending or raise taxes just because inflationary pressures are growing. There are "common pool" problems associated with demand-driven inflation: if local governments are engaged in competitive development, it is not in the interest of any single one to slow its local economy just because inflation is picking up at the national level. It is at the national level that government can act to cool inflation-by restricting spending or raising taxes (or raising interest rates and imposing credit rationing).

We thus agree with the results of ADB Report 2013-3 (cited above) that argues for reform of the tax system, increasing the share of the central government's budget devoted to social spending, and reducing the fiscal burden imposed on local government. Moving toward a more progressive tax structure reduces the burden on poor communities and individuals. Progressive income taxes also make tax revenues pro-cyclical (rising in a boom and falling during a slump) which acts as an automatic stabilizer. While that is a problem for local governments (revenues fall when social needs rise), it is not a problem for the sovereign government, which can run budget deficits as necessary to stabilize income. There is no reason to match central government tax receipts with expenditures at any point in the cycle; what is necessary, instead, is for the budget stance to move against the cycle (tightening in when the economy is in danger of overheating and loosening when growth slows). The danger faced by excessive sovereign government budget deficits is inflation, not insolvency. 
Returning to the three balances approach detailed above, the overall government balance must equal the sum of the domestic nongovernment balance plus the external balance. Policy should strive for that to occur at the desired growth rate of the economy. There is no unique government budget outcome consistent with noninflationary growth at the desired level; it depends on the other two balances - which in turn are determined complexly. If China runs a current account surplus of $2 \%$ of GDP, then a budget deficit of $2 \%$ allows the domestic nongovernment sector to run a surplus of $4 \%$. Currently that has occurred at a growth rate above $7 \%$, but there is nothing inevitable about that. If the domestic nongovernment sector decided to spend more of its income (save less) — say, run a surplus of only 1\% of GDP--then it is possible that a budget deficit of $2 \%$ would be too great - inflationary - and so balance would be restored with some combination of a higher domestic nongovernment surplus, a lower budget deficit, or a lower current account surplus. On the other hand, if the domestic nongovernment sector retrenches - tries to save, say, 10\% of GDP - then the economy slows and the balances adjust (domestic nongovernment sector surplus is less than 10\%, the budget deficit rises, or the current account surplus rises). In other words, one needs to take account of all three sector balances and as well the growth rate and inflation rate - one cannot arbitrarily set a goal for the government budget balance in isolation.

To conclude this section, it would be a mistake to pursue arbitrarily chosen deficit or debt targets for the central government. If anything, fiscal policy reform should put more emphasis on central government spending, and reduce responsibilities of local governments - or provide more funding for them from the central government. Local governments need to adopt tighter budgets - either by shifting more responsibilities to the central government or by creating additional regular sources of funding flowing from the central government to local governments. Both tax policy and spending should become more progressive, to increase provision of public services and public infrastructure to poor communities while relieving tax burdens there. Social spending of the central government probably needs to be doubled, relative to GDP, to bring China in line with other middle income countries.

Central government has the policy space to achieve these reforms. It is the sovereign currency issuer, so affordability is not the problem. Rather, increased spending must be phased in at a pace such that it does not fuel inflation. Sovereign government does not face a financing constraint; rather, the main problem is the inflation barrier. 


\section{b) Monetary Policy}

Western central banks have moved from generally loose money or reserve targets to explicit interest rate targets (often the overnight interbank lending rate). In many nations some type of a Taylor Rule is followed such that the interest rate target is adjusted with a view to controlling inflation (a few nations adopt explicit inflation targets). However, central banks also include other goals such as low unemployment, reasonable economic growth, exchange rate stability, and financial stability. It is well recognized that it is difficult to hit a variety of targets with just one instrument, however. Both the US Fed and the Bank of Japan have supplemented interest rate targets with "quantitative easing". Further, central banks generally play some role in regulating and supervising financial institutions.

The PBC also uses a range of policy instruments, as discussed above. China operates with a managed exchange rate and managed capital flows - these help to maintain domestic financial stability. The PBC issues bills to help manage reserves; it engages in open market operations in both its own bills and in treasury debt. It also uses the discount window, and pays interest on excess reserves. It controls bank lending and deposit rates. It has substantial, albeit largely implicit, direct control over banks. Finally, it has a dual mandate of stabilizing the currency and maintaining robust growth; it has an acknowledged but implicit mandate to maintain financial stability.

In comparison to Western central banks, the PBC probably has greater influence on its commercial banks and thus on formal credit markets. However, there is a growing shadow banking sector that is more difficult to control. It is probable that control of the formal sector actually increases the incentive to move activity to the shadow bank sector. Indeed, it appears that commercial banks are heavily involved in shadow banking. It is argued that the PBC keeps deposit interest rates in the commercial banks low to allow "zombie" banks to carry nonperforming loans; this "financial repression" probably contributes to growth of shadow banking where interest rates are considerably higher.

Various proposals for policy change include ending "financial repression", moving to inflation targets, dealing with zombie banks, freeing exchange rates and capital flows, increasing regulation and supervision of shadow banks, and internationalizing the RMB. In addition, we should consider possible implications for monetary policy if the main fiscal policy 
recommendation discussed above — relaxing the central government's budget—were followed. Let us quickly address each.

An argument for allowing interest rates to rise is that this will encourage more saving and hence promote investment. Yet China already has very high investment rates. Further, as discussed above, the domestic private sector surplus is equal to the balances of the government and foreign sectors. If the central government relaxes fiscal policy, the budget deficits will increase the private sector surplus (holding the foreign balance constant). While it makes sense at a micro level to argue that encouraging saving by households would generate more loanable funds for investment, at the macro level sectoral balances dictate a different relationship. (This is related to both the "leakages and injections" approach and the "paradox of thrift".) It is not a coincidence that Asian economies typically have high saving rates - not only do they have high investment (hence, the saving leakages equal the investment injections) but they also have current account surpluses (allowing domestic saving to exceed investment so that the private sector has a surplus). If they also have a government budget deficit then the private sector's surplus (saving less investment) is equal to the sum of the current account surplus and the government deficit.

Further, low policy interest rates keep spending on interest low-benefitting debtors such as state owned enterprises, small business, and local and national government. While the sovereign central government can always afford to pay higher interest, devoting a larger share of the budget to interest payment is probably not a good idea as interest income is likely skewed to higher income brackets. Instead, it is probably better to target central government spending to social programs, as discussed above. There is a well-known "sustainability" relation between interest rates and growth rates: if interest rates are below growth rates, then the debt-to-income ratio will not rise uncontrollably so long as the "primary" deficit (this is the budgetary balance excluding interest payments) is controlled. More generally, higher interest rates would tend to increase the share of national income flowing to higher income households, exacerbating inequality.

However, low official interest rates encourage shadow banking where earnings can be higher. Hence, to make the official rates effective, the PBC will need to get more control over the shadow bank sector. This is not easy. In the West, the reaction to competition from the less regulated sector was to reduce regulations across the financial system-leveling down. This, 
arguably, contributed to the evolution of the financial system toward fragility that finally resulted in the GFC. The potential benefits from "leveling up" in China appear to be significant even if the process will be difficult. It is particularly difficult to regulate local, informal credit markets - but that is probably not essential. It would be easier to reduce participation by commercial banks and large nonfinancial enterprises in the shadow banking sector-and that is the more important avenue to exerting control over total credit activity.

If China's central government fiscal stance relaxes — as recommended above — more national government debt will be issued. In that case, the PBC will issue fewer bills as treasury debt will be sufficient to drain a larger portion of undesired excess reserves. From the sovereign currency perspective there is no significant difference between PBC bills and treasury bills or bonds: in both cases, these offer a higher interest alternative to the low rate paid on reserves. With respect to insolvency or default risk, there is no difference between treasury and PBC debt - there is no chance of involuntary default on either of them. Operationally, they also serve the same purpose, which really can be thought of as an instrument to achieve monetary policy, not as a "borrowing" operation. The sale of bills and bonds drains reserves that otherwise might place downward pressure on the overnight interest rate. Hence, the PCB would simply move from its own bills to treasury debt to supply or drain reserves.

\section{c) Exchange Rate Policy (and Capital Controls)}

There should be no hurry to relax control over exchange rates or capital flows. Today the global financial system remains fragile, dominated by speculative flows. This is not the time to open China to short-term speculation. Another major financial crisis remains possible. While the West is discussing reigning in financial excesses, it has not yet put in place the reforms that would attenuate excessively risky behavior. Managing exchange rates and capital flows helps to protect China from externally induced financial instability. Eventually China will want to move toward greater flexibility of its exchange rate in order to maintain domestic policy space. As discussed, tight control of the exchange rate can be maintained only in the presence of sufficient foreign currency reserves. However, with a current account surplus as well as managed capital flows, China has ample policy space even with managed exchange rates. As the current account balance moves toward deficit and as China relaxes control of capital flows, it will need to allow more flexibility of the exchange rate. 
The RMB is already increasingly used in international trade - for example in invoicing. China probably should continue to increase international use of its currency. However, for the near future, the RMB will remain relatively unimportant compared to the dollar and a handful of other currencies that are used as international reserve currencies. As discussed, most international dollar "flows" have to do with portfolios rather than trade. With a current account surplus and with managed capital flows, the RMB is not well-situated to become a major international reserve currency. There is little doubt that that will eventually change, but it should be done at a measured pace. China has a huge stock of international currency reserves and still runs a current account surplus so new reserves are still flowing into the PBC. That means that China has a sufficient supply to manage its exchange rate and to finance imports using foreign currency reserves. There is little need for international currency reserves at the PBC beyond those two uses. In other words, China can use its stock of international currency reserves as it moves toward internationalization of the RMB at a measured pace.

\section{LESSONS FROM THE GFC}

We believe that the problems within the EMU in the aftermath of the GFC are instructive for China. By construction of the euro system, each member nation gave up its own currency and adopted the euro. This is even more extreme than a fixed exchange rate or currency board arrangement - it is effectively adopting a foreign currency. While each nation retained a central bank, these had to clear accounts in the euro. System-wide monetary policy was maintained by the ECB, which sets the overnight interest rate target. The ECB is not supposed to get involved in fiscal policy - each member state is responsible for its own fiscal policy. If a country were to experience problems in selling government bonds, the ECB was not supposed to directly or even indirectly facilitate sales. For that reason there was always the possibility that interest rates on government debt issued by the member states would diverge. The ECB does, however, help member central banks to clear accounts with one another (via Target 2 arrangements). This became important when reserves tended to flow from the periphery nations to the stronger, central countries. The flows could be on current account (due to exports from Germany to Greece, for example) or on capital accounts (through a "run" on deposits of periphery banks into German banks, for example). This helped to ensure "par clearing"-meaning that a euro deposit 
in Greece is expected to be worth the same as a euro deposit in Germany. Recently, however, "par" was broken when Cyprus was forced to "haircut" bank deposits in its bank.

The biggest problem turned out to be constraints on fiscal policy. While there was an EMU-wide monetary policy authority, there was no equivalent system-wide fiscal authority. Instead, and by design, each individual nation had its own fiscal authority. The Maastricht criteria established maximum debt-to-GDP and deficit-to-GDP ratios, although these were not strictly enforced. In any event, as it turned out these criteria were far too lax for nations that had effectively given up currency sovereignty (by adopting a foreign currency). By comparison, US states have also effectively adopted a foreign currency - the dollar - and are "users" not "issuers" of the currency (indeed, the US Constitution forbids currency issue by the states), but none of them had deficit or debt ratios even close to Maastricht criteria on the eve of the GFC. US states would quickly be downgraded by ratings agencies if they submitted budgets with a planned deficit, and even relatively highly indebted states had debt ratios to state GDP in the range of $15 \%$ (one-quarter the Maastricht criteria).

Additionally, individual nations were responsible for social spending and for regulating and protecting their own banks. When the GFC hit, some nations found their banks in trouble and social spending rising even as tax revenue fell. That caused deficits and debt ratios to rise, which scared markets. Interest rates on government debt quickly diverged, with troubled countries succumbing to an interest rate-debt trap as rising interest rates increased budget deficits, raising debt and triggering credit downgrading. For that reason, even nations with only moderate debt ratios before the crisis were put in dire straits and had to seek outside assistance (from the ECB and international agencies) - which came with strings attached (budget cutting austerity). While assistance to date has prevented a 1930s-style depression and debt deflation, conditions continue to deteriorate for many of the members of the EMU.

The lesson is that the EMU needs a strong fiscal center. ${ }^{29}$ It was a mistake to separate the currency from the fiscal authority. Since individual nations are fiscally constrained, they were not able to deal with the exigencies of a crisis. Note that the US and the UK were able to mount fiscal stimulus packages (and China's fiscal stimulus was even larger, relative to the size of its GDP); more than that, their central banks were able to pursue unprecedented actions to protect

\footnotetext{
${ }^{29}$ For a detailed analysis, see "Fiddling in Euroland as the Global Meltdown Nears", Dimitri B. Papadimitriou and L. Randall Wray, Levy Public Policy Brief No. 122, 2012, http://www.levyinstitute.org/pubs/ppb_122.pdf.
} 
their respective financial systems (in the case of the US, the Fed originated over \$29 trillion in loans in response to the crisis). ${ }^{30}$ And not, also, that no matter how big the government deficits in the US, the UK, and Japan were, their central banks were able to hold interest rates close to zero-market "vigilantes" could not interfere in central bank interest rate setting even as ratings agencies downgraded national debt.

By contrast, in Europe only the system's central bank (the ECB) was able to respondthe European Parliament did not have the fiscal policy space to help. While neither the US nor the UK pursued fiscal stimulus on the scale needed, they could have done more and in any case they did enough to prevent the US and UK from falling into a depression. Some parts of the EMU are in depression, and recovery is not yet on the horizon. Individual national central banks cannot prevent market spreads (the difference of interest rates between those on their national debt and those on the debt of the strongest nation-Germany) from rising. They are subject to the dictates of the ECB and international lending agencies like the IMF. They gave up currency sovereignty and that meant that they lost fiscal and monetary policy space.

The lesson for China is that it needs to keep its fiscal and monetary policy independence, which requires that it operate its own sovereign currency. To deal with a financial crisisshould one suddenly appear-China will need the maximum policy space. It might even need to relax management of its exchange rate to deal with the crisis. As a currency issuer, China is able to do this. It can hold its interest rate as low as it wishes, and it can create a sufficiently large fiscal stimulus should the need arise.

Finally, China might learn from the US experience of operating the global reserve currency in a crisis. Much of the Fed's "bail-out" was aimed at foreign financial institutions and central banks. The downside of a reserve currency is that one's central bank becomes responsible for the global financial system. Dollar denominated liabilities (including derivatives) are in the hundreds of trillions of dollars. In the crisis, the Fed became responsible for that. This cannot be forgotten. It is hard to see how international trade in goods and services can be denominated in a particular reserve currency without also having those transactions layered with financial transactions also denominated in that currency — with debt layered on debt in an amount many orders of magnitude greater.

\footnotetext{
${ }^{30}$ See "Improving Governance of the Government Safety Net in Financial Crisis", L. Randall Wray, Research Project Report, April 9, 2012, Levy Economics Institute, http://www.levyinstitute.org/publications/?docid=1518.
} 


\section{CONCLUSIONS}

This project presents an analysis of a number of policy issues now facing China, based on a sovereign currency framework. We analyzed the monetary and fiscal options available to China using its sovereign currency. We used the framework to explain how China might be able to continue to grow, develop, and reduce poverty in the context of a "dollar standard" world. Our project analyzed recent Chinese growth and the domestic as well as global "imbalances" from the sovereign currency vantage point. We then turned to the prospects for continued growth in China given a Western recovery that remains highly problematic.

Some commentators have recently begun to discuss a possible "fiscal reform" in China. The sovereign currency approach is particularly well-prepared to investigate issues surrounding fiscal reform and to make policy recommendations. In discussing fiscal reform it is important to recognize the options available to a nation that adopts a sovereign currency.

Our main conclusions are the following:

1. China's fiscal and monetary policy space is similar to those of other monetarily sovereign nations such as the US, the UK, and Japan;

Therefore,

2. "affordability" is not an issue: China's central government can always make all budgeted payments as they come due; and

3. the overnight interest rate is a policy variable, determined by the PBC.

Further,

4. these results do not depend on internationalization of the sovereign currency;

5. nor do they require that China "liberalize" capital flows.

China's main imbalance is domestic and consists of local government budgets that are too loose while the central government's budget is too tight. While local governments do face a solvency constraint, the central government—as a currency issuer—does not.

6. Following from those conclusions, we recommend that the central government's fiscal stance should be gradually relaxed so that local government and corporate budgets can be tightened. By loosening the central government's budget but tightening local government and corporate budgets at a measured pace, China can avoid depressing growth or sparking excessive inflation. 
Most importantly China should resist any pressure to adopt policies that failed in the West. The euro "experiment" shows the problem created by adopting a "foreign" currency; currency board arrangements as well as rigid fixed exchange rate pegs would also limit domestic policy space. Both monetary aggregate targeting as well as rigid inflation targets have proven to be mistaken. Efforts to tie fiscal policy to pre-conceived notions of what is "sound finance" (such as balanced budgets, deficit targets, or debt-to-income ratios) have also been shown to be based on misconceptions. 


\section{REFERENCES}

Asian Development Bank (ADB). (2010) Rebalancing Growth in the PRC: The Role of Fiscal Policy. Observations and Suggestions No. 2010-4. Manila, Philippines: Asian Development Bank.

- (2011) The Challenges of Middle Income Transition in the PRC. Observations and Suggestions No. 2011-2. Manila, Philippines: Asian Development Bank.

China (2012) Growing Beyond the Low-Cost Advantage: How the People's Republic of

Can Avoid the Middle Income Trap. Manila, Philippines: Asian Development Bank.

Akram, T. (2013) Macroeconomic Outlook and Monetary Policy View: No Exit from the Wasteland? ING Global Macro View from Atlanta, GA. ING Investment Management Report. Atlanta, GA.

Auci, S., L. Castellucci, and M. Coromaldi. (2013) Does Cutting Back the Public Sector Improve

Efficiency? Some Evidence from 15 European Countries, Vol. 11. CEIS Working Paper No. 274. Rome, Italy; Center of Economic and International Studies (CEIS).

Blanchard, O., and D. Leigh. (2013) Growth Forecast Errors and Fiscal Multipliers. IMF Working Paper No. 13/1. Washington, DC: International Monetary Fund.

Eichengreen, B.(January 2010) "Renminbi Internationalization: Tempest in a Teapot?" ADB Distinguished Lecture, delivered in Manila, January 11, 2013. Printed in the Asian Development Review, vol. 30, no. 1, pp. 148-164

Felipe, J. (2012a) Tracking the Middle-Income Trap: What is It, Who is in It, and Why? Part 1. ADB Economics Working Paper Series No. 306. Manila, Philippines.

- (2012b) Tracking the Middle-Income Trap: What is It, Who is in It, and Why? Part 2. ADB Economics Working Paper Series No. 307. Manila, Philippines.

- (2013) Why Has [the People's Republic of] China Succeeded-And Why It Will Continue to Do So. Cambridge Journal of Economics, Vol. 37. pp. 791-818. Cambridge, UK.

Feng, S. (2009) Study on Local Government SIVs and Local Government Debt. China State Finance, Vol. 18. pp 43-45. Beijing, PRC.

Fullwiler, S. Kelton, S. and Wray, L.R. (2012) "Modern Money Theory: A Response To Critics", by, January 2012, PERI Working Paper Series, Number 279, http://www.peri.umass.edu/fileadmin/pdf/working_papers/working_papers_251300/WP279.pdf 
Goodfriend, M., and Prasad, E. (2006a) "Monetary policy implementation in China"Presented at HKIMR-BIS conference on "Monetary policy approaches and implementation in Asia". This paper draws extensively upon the authors'

_ . (2006b) "A Framework for Independent Monetary Policy in China", IMF Working Paper WP/06/111. Available on the web at www.imf.org/external/pubs/ft/wp/2006/wp06111.pdf

Herndon, T., M. Ash, and R. Pollin. (2013) Does High Public Debt Consistently Stifle Economic

Growth? A Critique of Reinhart and Rogoff. Political Economy Research Institute Working Paper No. 322. Massachusetts: Political Economy Research Institute, University of Massachusetts.

Ito, H. and Volz, U. (2012) "The People's Republic of China and Global Imbalances from a View of Sectorial Reforms” ADBI Working Paper Series No. 393, Asian Development Bank Institute.

Magnus, G. (2013a) Hitting a BRIC Wall. The Globalist. Available at http://www.theglobalist.com

_ (2013b) [The People's Republic of] China and the End of Extrapolation. The Globalist. Available at http://www.theglobalist.com

—. (2013c) Is Asia's Miracle Over? The Globalist. Available at http://www.theglobalist.com

McKinnon, R. 2012. The Unloved Dollar Standard: From Bretton Woods to the Rise of [the People's Republic of] China. Oxford University Press, US. Monetary and Fiscal Operations in the People's Republic of China I 21

Rabinovitch, Simon. (Dec 2, 2012), "Uncertain Foundations, Published in the Financial Times (http://www.chinadaily.com.cn/opinion/2012-10/12/content_15812305.htm)

Shu, C. and Ng, B. (2010) "Monetary Stance and Policy Objectives in China: A Narrative Approach.” China Economic Issues, Number 1/10, January 2010, Hong Kong Monetary Authority.

J. Sun. (2013) Chinese Local Government Debt, Current Situation, Problems and Strategy. Friends of Accounting, Vol. 3. pp. 58-66. Beijing, PRC.

Veneroso, F. (2012) "China: Solow, Minsky”, Presentation at the Hyman P. Minsky conference on Financial Instability, Debt, Deficits and Unstable Markets, organized by the Levy Economics Institute, November 26-7, 2012, in Berlin, Germany. 
WANG XIAOTIAN. (28 Feb 2013). "Efficiency of China's Economy 'Sliding'." China Daily. See http://www.chinadaily.com.cn/china/2013-02/28/content_16262459.htm

Wray, L. R. (2010a) Does Excessive Sovereign Debt Really Hurt Growth? A Critique of This Time is Different by Reinhart and Rogoff (with Y. Nersisyan). Levy Economics Institute Working Paper No. 603. New York: Bard College.

- (2010b) Excessive Liquidity and Bank Lending in [the People's Republic of] China: A Modern Money Perspective (with Xinhua Liu). International Journal of Political Economy. Volume 39, Number 3. New York: M. E. Sharpe.

. (2011) Is the US on an Unsustainable Path? Lessons from the Past as Detailed by Reinhart and Rogoff (with Y. Nersisyan). In O. Torsten Niechoj, Engelbert Stockhammer, Achim Truger, and Till van Treeck, eds. Stabilizing an Unequal Economy? Public Debt, Financial Regulation, and Income Distribution. Marburg, Germany: Metropolis.

- (2012a) Modern Money Theory: A Primer on Macroeconomics for Sovereign Monetary Systems. New York: Palgrave-Macmillan.

. (2012b) Lessons for [the People's Republic of] China from the Crisis in Euroland (with X. Liu). The Chinese Economy, Vol. 45. pp. 6-25. New York: M. E. Sharp.

- (2012c) The Nature of Money: From the View of Post-Keynesian Economics (with Jinxing Guo). China Review of Political Economy, No.1. Beijing: International Center for Social Science, Renmin University.

. (2012d) Godley Got it Right. In D. Papadimitriou and G. Zezza, eds. Contributions to Stock-Flow Modeling: Essays in Honor of Wynne Godley. New York: Palgrave Macmillan.

_. (2012e) "Improving Governance of the Government Safety Net in Financial Crisis." Research Project Report, April 9, 2012, Levy Economics Institute, Annandale-OnHudson, NY, Available at: http://www.levyinstitute.org/publications/?docid=1518.

Xiao Gang. (2012-10-12) "Regulating Shadow Banking." China Daily See http://www.chinadaily.com.cn/opinion/2012-10/12/content_15812305.htm

Zhou, Y. (2003) "The Analysis On Treasury Account System In China”, Journal of Financial Management Cadre Institute in Fujian, 2003 (1), pp48-53. 